\title{
Technical and Economical Comparison of Supplying Energy from Combined Solar-Wind Power Plants in Lieu of Natural Gas Transmission Lines
}

\author{
Zeinolabedin Sadeghi ${ }^{1}$ \\ Hamidreza Horry ${ }^{2}$ \\ Seyedeh Sakineh Sadeghi Nasaj \\ z_sadeghi@uk.ac.ir \\ horryhr@uk.ac.ir
}

Received: 17/09/2021 | Accepted: 10/07/2021

\begin{abstract}
Transmission of gas from extraction wells is a precondition for transferring this resource to consumers, which in turn requires a comprehensive system in production, transmission, and distribution. The transmission cost varies depending on the transmission distance, route difficulty, number of stations, and decrease or increase in pressure. Hence, concentrating on another energy resource with low investment requirements that could be delivered for consumption at the production area can lead to reduction in costs and time efficiency as well. The present study attempts to compare the combined solar wind power plants with the gas transmission, in terms of cost and revenue in Andica county, located in Khuzestan province, using simulation tools for renewable power plants. The findings suggest that combined power plants have significantly lower cost than gas transmission power lines in terms of investment requirements. The operation cost of gas transmission lines has a significantly higher price in relation to its ensuing revenue, since the operation costs of combined power plants are covered by annual revenue from the electricity supply. In general, it should be said that the high cost of capital for gas transmission, considering the annual income from its sale, refutes its economical profit, while the combined power plant, due to the lower cost of capital than gas transmission, produces more revenue than gas sales, so it is more economically justifiable than gas transmission.
\end{abstract}

Keywords: Combined Power Plants, Gas Transmission Lines, Costing, Renewable Energy, RETScreen Software.

JEL Classification: Q21, Q31, Q41.

1. Associate Professor, Department of Economic and Management, Shahid Bahonar University of Kerman, Kerman, Iran (Correspondence Author).

2. Associate Professor, Department of Economic and Management, Shahid Bahonar University of Kerman, Kerman, Iran.

3. M.A. Student of Energy Economy, Shahid Bahonar University of Kerman, Kerman, Iran. 


\section{مقايسه اقتصادى و فنى تامين انرزى از نيروكَاه

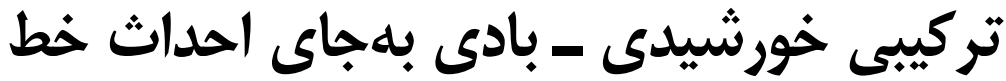 انتقال كَاز طبيعى خوريدي \\ z_sadeghi@uk.ac.ir

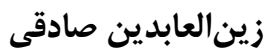

دانشيار دانشكده اقتصادو مديريت، دانشكاه شهيد باهنر كرمان، كرمان، ايران (نويسنده مسئول). horryhr@uk.ac.ir

حميدرضا حرى

دانشيار دانشكده اقتصاد و مديريت، دانشخاه شهيد باهنر كرمان، كرمان، ايران.

سيده سكينه صادقى نساج

دانشجوى كارشناسى ارشد اقتصاد انرزى، دانشخاه شهيد باهنر كرمان، كرمان، ايران.

مقاله بزوهشى

هذيرش:

دريافت: 9/F/•

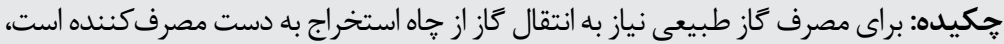

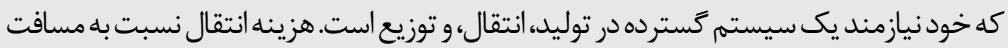

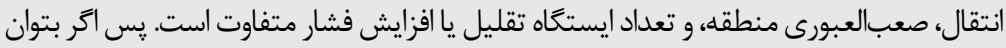

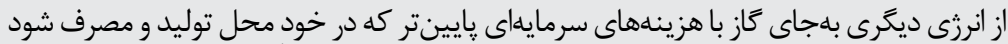

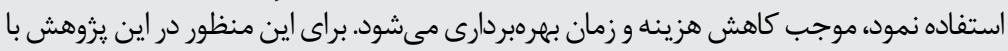

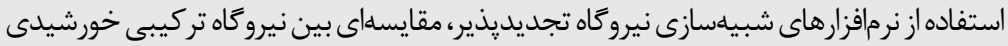

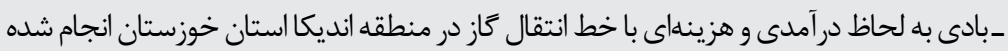

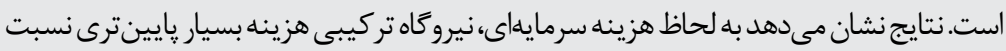

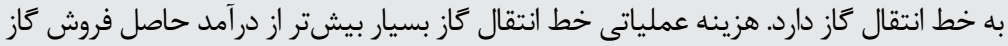

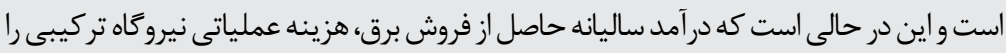

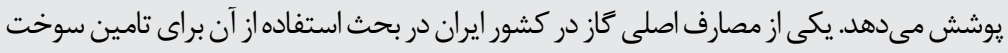

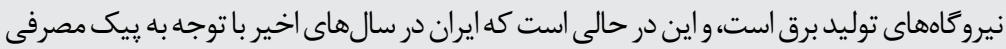

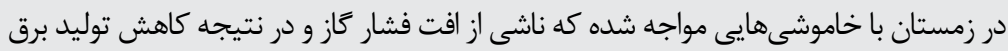

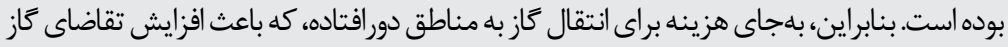

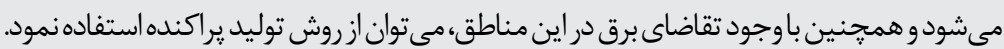

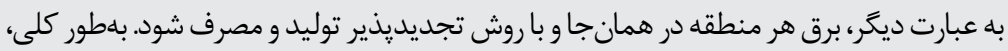

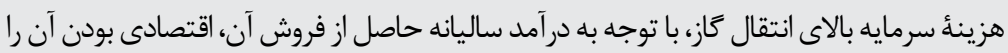

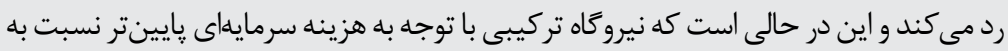

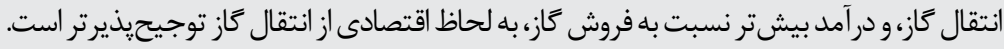
كليدوازهها: نيروكاه تركيبى، خط انتقال گاز، هزينهيابى، استان خوزستان، انرزى تجديديذير،

RETScreen نرمافزار طبقهبندى ن21, Q41, Q31 :JEL 


\section{مقلفمه}

بهطور كلى، توسعه اقتصادى به عنوان يك ركن اساسى در مجموعه سياستها و خطمشىهاى

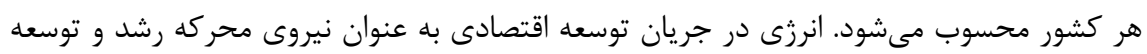

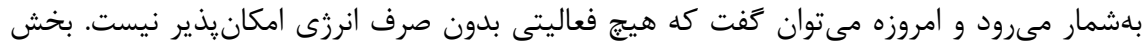
انرزى به عنوان يكى از بخشهاى اقتصادى ـ اجتماعى تاثير بسزايى بر ساير بخشها دارد (اسماعيلنيا

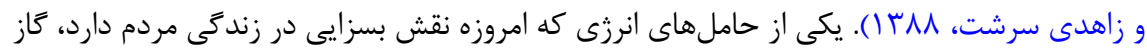
طبيعى است. در واقع، كاز طبيعى به عنوان مههمترين حامل انرزى محسوب مىشود كه سهم بسيارى از مصرف انرزى در بخشهاى اقتصادى، بلويره در بخش مصرف خانوار دارد. همجنين، مصرف عاز طبيعى با توجه به محدوديت حاملهاى انرزى تجديديذير از يك طرف، و رشد جمعيت جهان از بردي

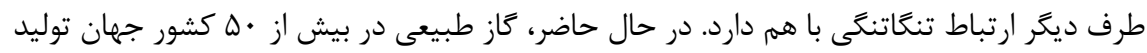

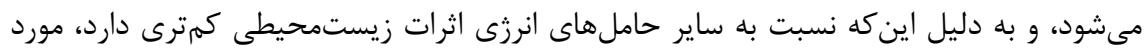

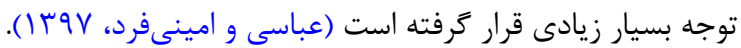

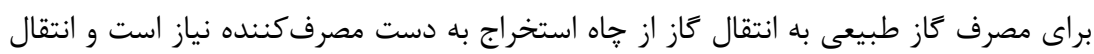
كاز طبيعى به صورت كارامد و موثر از منطقه توليد به منطقه مصرف نيازمند يك سيستم كسترده در

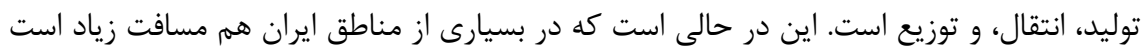
و هم نقاط صعبالعبور وجود دارد. يس در كنار زمانبر بودن، به لحاظ صرف هزينه و سرمايه نيز

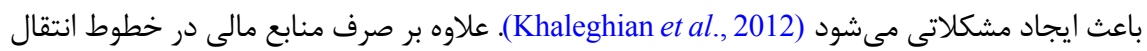

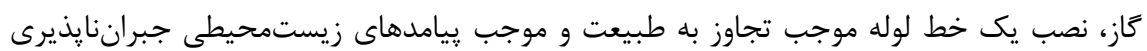

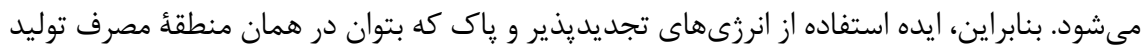

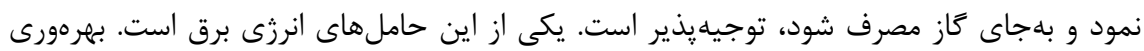

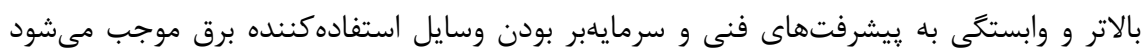

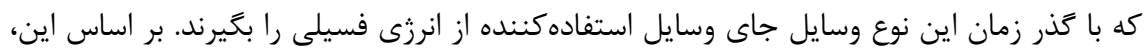
بيشتر كشورهاى جهان در جار جوب قانونى به منظور تشويق مردم و نهادهاى اقتصادى به استفاده از

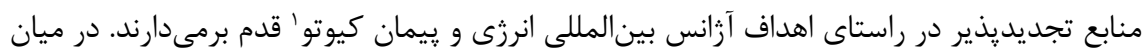
اين اهداف، براى ييشبرد عرضه و تقاضاى انرزى در كشورهاى در حال توسعه، جايكزين كردن منابع I. Kyoto Protocol: يك پِيمان بينالمللى است كه به دليل گرم شدن زمين در دهdهاى اخير، براى كاهش

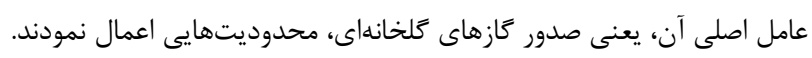


Maji,) انرزى پاك و افزايش بهرهورى مصرف انرزى در رأس دستور كار اين نهادها و پيمانها قرار دارد

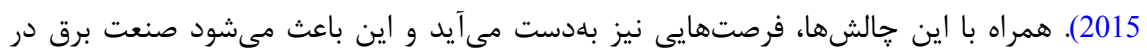

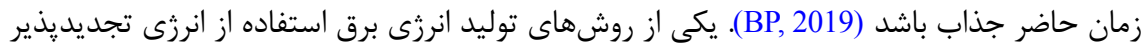
خورشيدى و بادى است كه اين امكان را دارد در همان محلِ مصرف، توليد شود. به عبارت ديكر،

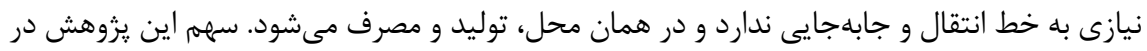
ادبيات اين است كه به صورت همزمان به ارزيابى و مقايسُٔ اقتصادى دو نوع تامين انرزى تجديديذير

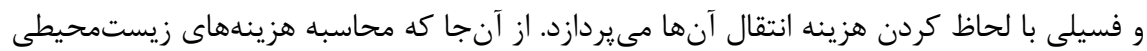

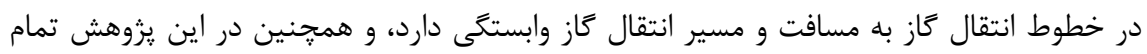

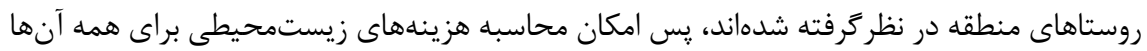
مقدور نيست. بنابراين، هزينههاى زيستمحيطى در نظرگرفته نشدهاند. فقط هزينهای اجتناب از آلودگى با استفاده از منابع تجديديذير لحاظ شده است. اين مطالعه به دنبال ياسخكويى به اين يرسش

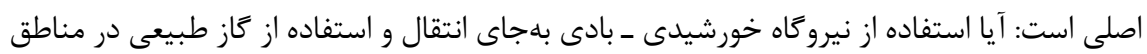

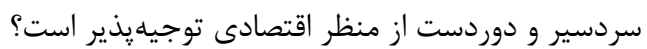

بسيارى از صاحبنظران، استفاده از نيروكاههاى خورشيدى و ساير انرزىهاى نو را راهحلى براى جايكزينى گاز طبيعى مى دانند، زيرا نيرو Fاههاى خورشيدى نسبت به ساير مراكز توليد انرزى برق فسيلى

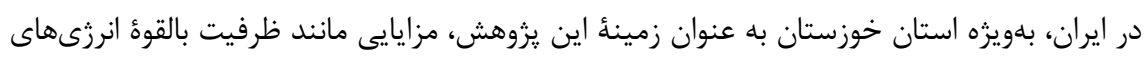

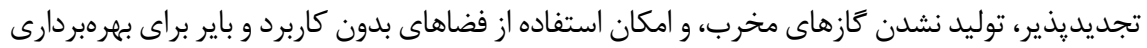

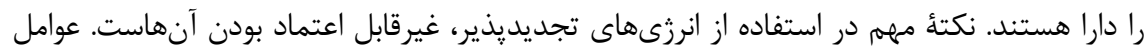
محيطى بسيار نامشخص و وابسته به مكان هستند. از طرفى، انرزى هاى تجديديذير مانند باد و خورشيد لمريد

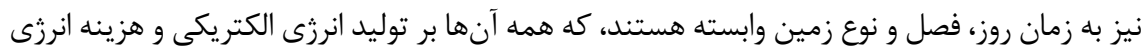

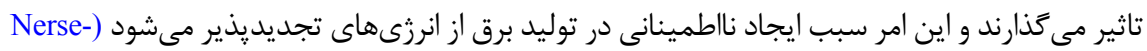
(sian, 2016 بنابراين، شناخت دقيق و مناسب نوع انرزى تجديديذير، عوامل موثر بر آن، راههاى محاسبه و اندازمكيرى خروجى براى محاسبات اقتصادى از اهميت بسزايى برخوردار است. طبق آمار موجود، توليد

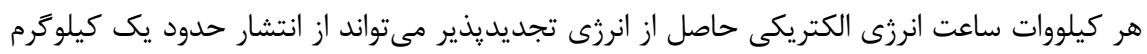
كربن دى اكسيد در مقايسه با نيرو گاههاى سوخت فسيلى جلوگيرى نمايد (Wang et al., 2019). 
يكى از مزاياى انرزى باد آن است كه در زمستانها وزش باد سريعتر است و تداوم بيشترى

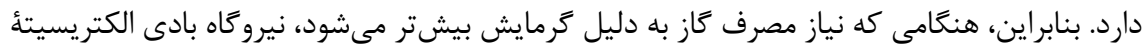

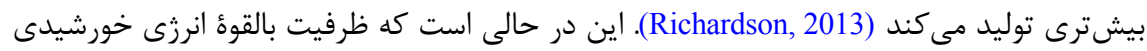
در استانهاى جنوبى كشور با توجه به تعداد روزهاى آفتابى بالا و صافى هوا، استفاده از اين انرزى را بسيار توجيه يذير مىنمايد. يزوهشهاى بسيارى در مورد استفاده از انرزىهاى تجديديذير، بلويرها انرزى خورشيدى و بادى، انجام شده كه بيشتر به مقايسه اقتصادى اين نوع انرزى با نيروكاه انرزى فسيلى يرداختهاند.

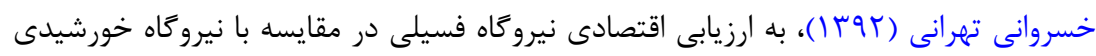

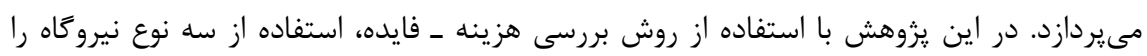
در ايران مورد مطالعه قرار مىدهد. نتايج يزوهش نشان مى مدهد، توليد برق در نيروكاه خورشيدى

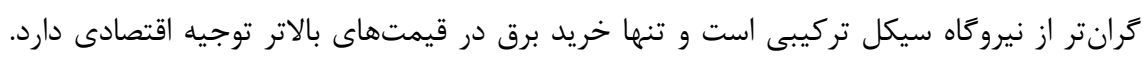

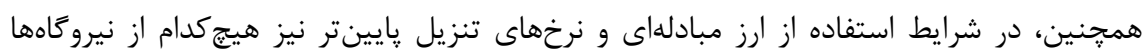

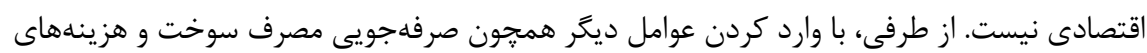

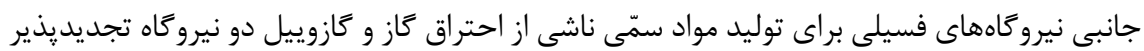

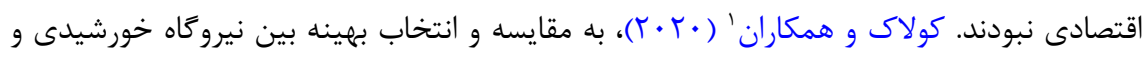

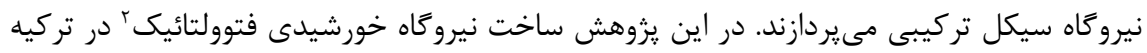

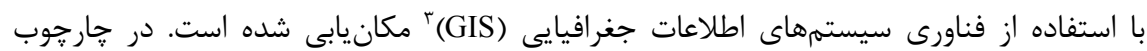
يروهش، عوامل موثر بسيارى ازجمله ظرفيت بالقوه انرزى خورشيدى، جادهها، خطوط انتقال انرزى،

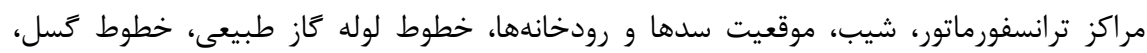

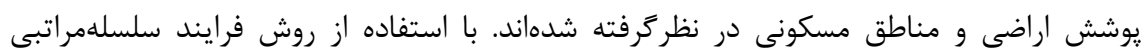
تحليلى، وزن عاملها محاسبه شد. در نتيجه تمام اين فرايندها، نقشهاى ارائه مى دهد كه مكانهاى بهينه را براى نيرو كامهاى انرزى خورشيدى نشان مى دهد. الموهلاوى و همكاران (

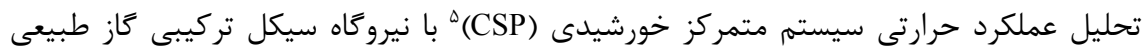

\section{Colak et al.}

2. Photovoltaic

3. Geographic Information System

4. Elmohlawy et al.

5. Concentrated Solar Power 
(NGCC)

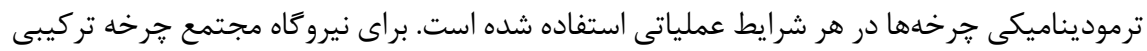

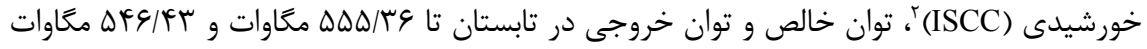

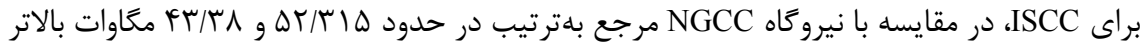

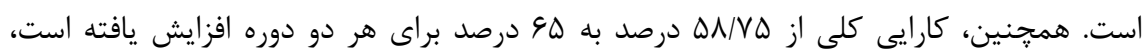

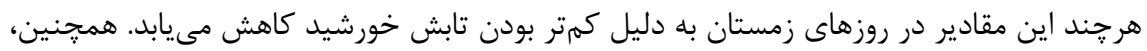

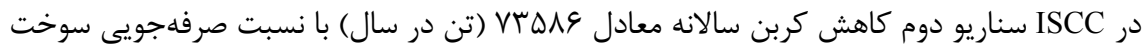

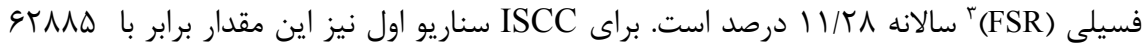

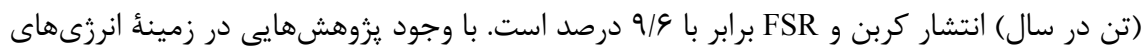
تجديديذير و مقايسه آن با مصرف انرزى تجديديذير، اما كمتر به موضوع جايكزينى اين انرزى بـها يرداخته شده است.

\section{روش اشناسى ثزوهش}

\section{نيروكاه تركيبى خورشيدى - بادى}

با توجه به ماهيت متناوب و قدرت غيرقابل ييشبينى از منابع انرزى تجديديذير مستقل مانند

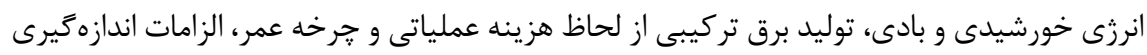
و تعمير و نكَهدارى سيستم بيشتر قابلاعتماد است (Ahmad et al., 2018). طراحى يك سيستم

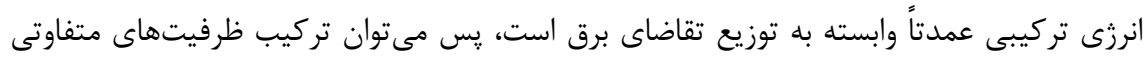

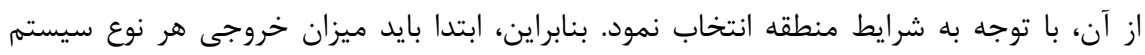
خورشيدى و بادى را محاسبه نمود.

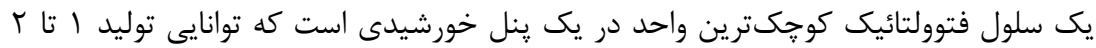
وات الكتريسيته دارد و از تركيب جند سلول خورشيدى يكى صفحه خورشيدى بلهوجود مى آيد كه

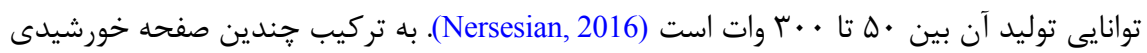

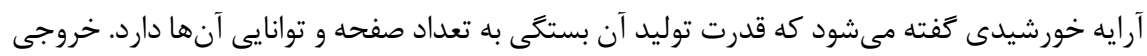

1. Natural Gas Combined Cycle 
قدرت آرايه خورشيدى فتوولتائيك را به صورت رابطه ( (1) مىتوان محاسبه نمود:

$P_{P V}=P_{P V, S T V} f_{P V} f_{\text {temp }}\left(\frac{I_{T}}{I_{T, S T C}}\right)$

در اين رابطه ${ }^{\prime} P_{P V, S T V}$

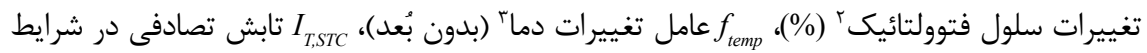

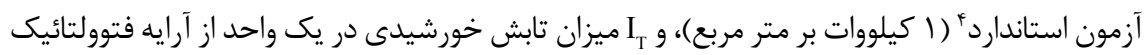
(كيلووات بر متر مربع) است، كه به صورت رابطه (r) تعريف و محاسبه مىشود (Ramli et al., 2016):

$I_{T}=\left(1+\frac{I_{d}}{I_{0}}\right) I_{b} R_{b}+I_{d}\left(1-\frac{I_{b}}{I_{d}}\right)\left(\frac{1+\cos ^{\beta}}{2}\right)\left(1+\sqrt{\frac{I_{b}}{I} \sin ^{3} \frac{\beta}{2}}\right)+\rho_{g}$

در اينجا I تابش افقى جهانى ه (كيلووات / متر مربع)، I تابش افقى فرازمينى ؟ (كيلووات بر متر

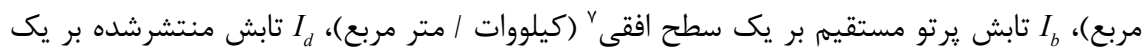

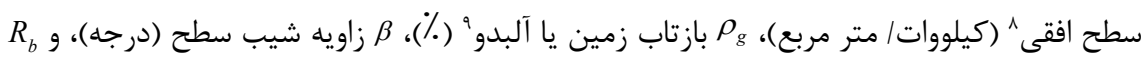

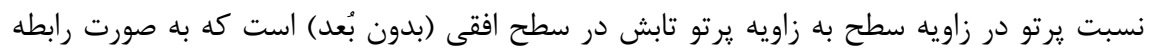
$R_{b}=\frac{\operatorname{Cos} \theta}{\operatorname{Cos} \theta_{z}}$

در اين جا $\theta$ مشخص كننده زاويه برخورد و

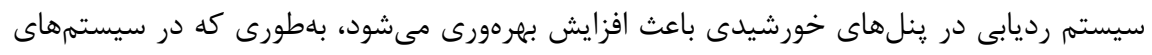

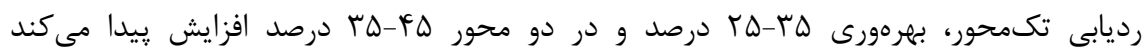
(Nersesian, 2016) حرارت يا دما است. در طول شب، دماى سلول خورشيدى همانند دماى محيط است، اما در طول

1. Standard Test Conditions

2. PV Derating Factor

3. Temperature Derating Factor

4. Incident Radiation at Standard Test Conditions

5. Global Horizontal Radiation

6. Extraterrestrial Horizontal Radiation

7. Direct Beam Radiation on a Horizontal Surface

8. Diffuse Radiation on a Horizontal Surface

9. Albedo 
روز كه خورشيد كامل است، دماى سلول خورشيدى مىتواند تا بيش از • ب درجه سانتيكراد از دماى

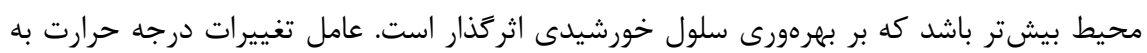

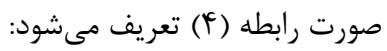

$f_{\text {temp }}=\frac{1+\alpha_{p}\left[T_{\alpha}+I_{T}\left(\frac{T_{C, N O C T}-T_{\alpha, N O C T}}{I_{T, N O C T}}\right)\right]-T_{C, N O C T}}{1+\alpha_{p} I_{T}\left(\frac{T_{C, N O C T}-T_{\alpha, N O C T}}{I_{T, N O C T}}\right) \frac{\eta_{m p, S T C}}{0.9}}$

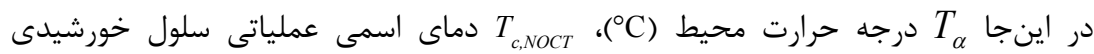
(NOCT) سانتيگراد)،

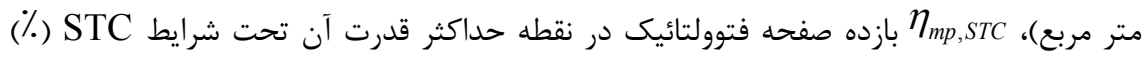

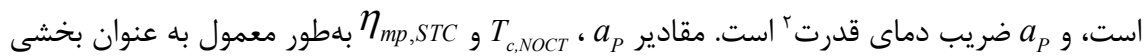
از دادههاى سلول خورشيدى توسط توليدكنند دماى اسمى عملياتى سلول خورشيدى، درجه حرارت سطح آرايه فتوولتائيك است كه در معرض

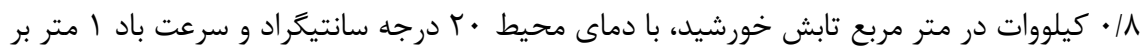

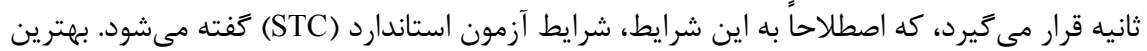

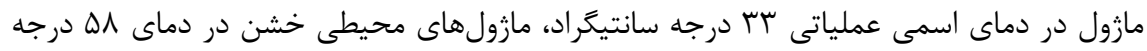

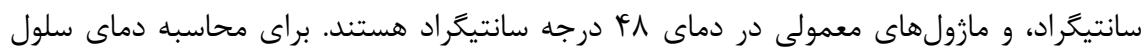
$T_{\text {Cell }}=T_{\alpha}+\frac{N O C T-20}{80} S$

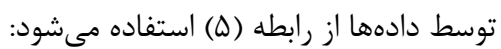
در اين رابطه S ميزان آفتابگيرى در هر مخاوات بر سانتيمتر مربع است. سرعت باد بر دماى سلول اثر گذار است. به عبارتى، دماى مازول در سرعت باد بالا، يايينتر و در سرعت باد يايين، بالاتر

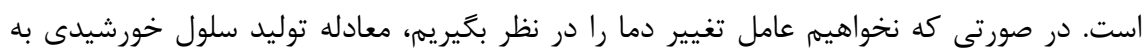
$P_{P V}=Y_{P V} f_{P V}\left(\frac{\bar{G}_{T}}{\bar{G}_{T, S T C}}\right)$ صورت رابطه (ع) درمى آيد: 
ظرفيت اسمى آرايه خورشيدى، YPV است (كيلووات)،

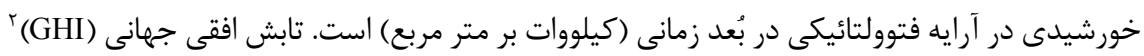
كل تابش خورشيدى در يك سطح افقى است. اين مجموع نور مستقيم عادى (DNI)"، تابش افقى

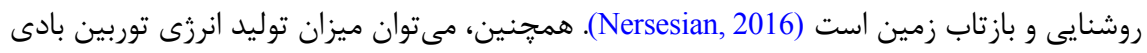
$P_{W}=\left(\frac{\rho}{\rho_{0}}\right) P_{W, S T P}$ را در سرعتهاى مختلف باد طبق رابطه (V) نيز محاسبه نمود:

جايى كه P توان واقعى خروجى توربين بادى (كيلووات)، Pر Pروجى قدرت توربين بادى

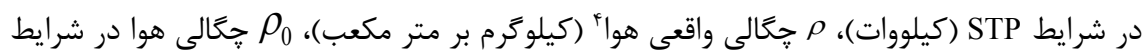

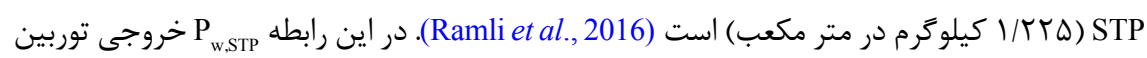

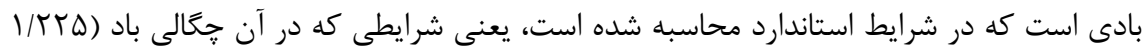

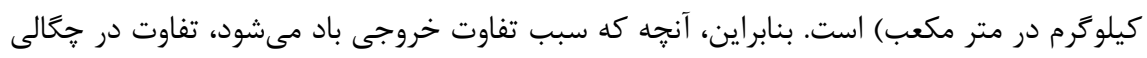

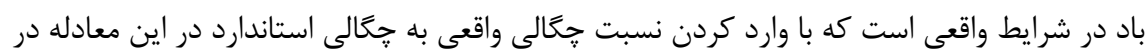

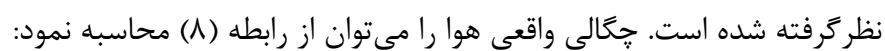
$\rho=\frac{1}{2} \rho_{0} A \sum_{i=1}^{n} P\left(V_{i}\right) V_{i}^{3}$ كه در اين رابطه

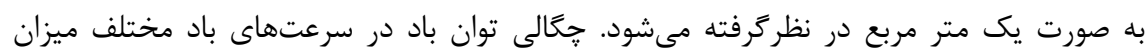

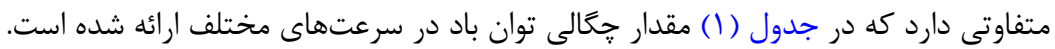

1. Solar Radiation Incident on the PV Array in the Current Time Step [kW/m2]

2. Global Horizontal Irradiance (GHI)

3. Direct Normal Irradiance (DNI)

4. Actual Air Density 


\begin{tabular}{|c|c|}
\hline$P\left(V_{i}\right) V_{i}^{3}$ & سرعت باد (متر بر ثانيه) \\
\hline$r v f / f l$ & $r-r$ \\
\hline $109 \cdot / 49$ & $r / \omega-\omega$ \\
\hline$\wedge \wedge q 4 / \cdot \Delta$ & $\Delta / \Delta-\Lambda$ \\
\hline ITFTI/AG & $\Lambda / \Delta-1 \cdot / \Delta$ \\
\hline IrqV·/VV & $\mid 1-1 \pi / 0$ \\
\hline AQVT/AT & $\mid f-19 / 0$ \\
\hline$\Delta \wedge r \Delta / \cdot q$ & IV-r. \\
\hline $\mid \Delta 9 V / \cdot r$ & $r \cdot / \Delta-r r / Q$ \\
\hline
\end{tabular}

\section{محاسبه هزينه}

\section{هزينه خط انتقال تاز؟}

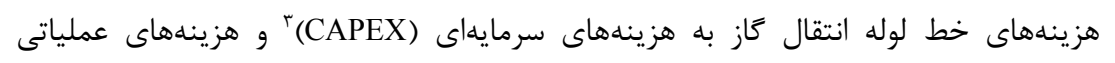
(OPEX)

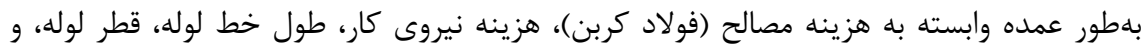

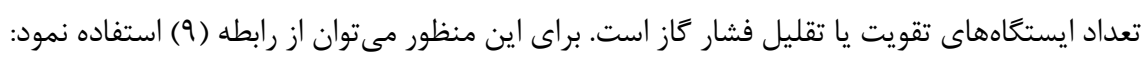
C $=42675 \mu \delta+\left(3 \times 10^{7}\right) a+1500 c$

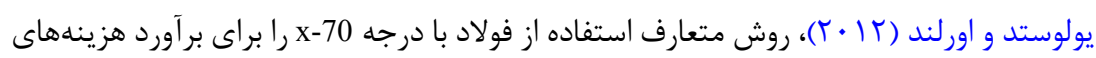

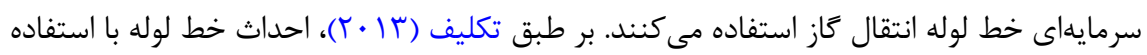

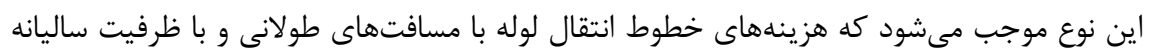

1. https://www.irimo.ir/far/index.php

3. Capital Expenditures r. همه هزينهها و محاسبههاى اين يزوهش برحسب دلار است. 
بالا، حدود • r درصد كاهش ييدا كند. منظور از X-70 نوع فناورى بكاررفته لوله خط انتقال است كه يكى اصطلاح تخصصى در توليد خطوط انتقال كاز و نفت است' و خارج از حيطه اقتصادى است. بر بر برد

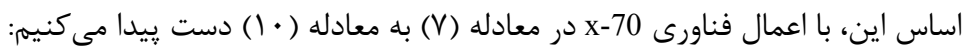
$\mathrm{C}=0 / 8(42675 \mu \delta)+\left(3 \times 10^{7}\right) \mathrm{a}+1500 \mathrm{c}$

در واقع، هزينههاى ساختوساز اين خط لوله با ضرب هزينه ثابت در قطر (H) برحسب اينج و

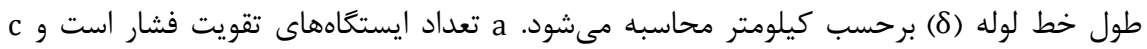
ظرفيت كلى از ايستعاههاى تقويت فشار برحسب اسب بخار است. بر اساس اينكه هزينههاى واقعى

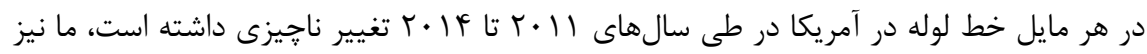

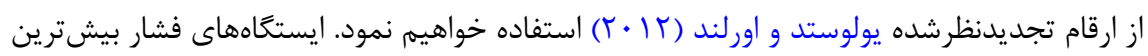

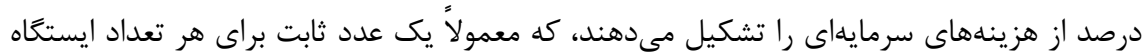

$$
\text { در نظر زرفته مىشود. }
$$

هزينههاى عملياتى خط انتقال گاز به دو دسته تقسيم مى شود: هزينههاى عملياتى و درصد

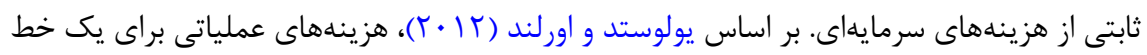
لوله بلهور معمول هزينههاى سالانهاى شامل سوخت ايستخاههاى تقويت فشار، تعميرات خط لوله،

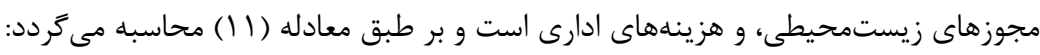
$\mathrm{O}_{\mathrm{p}}=\mathrm{C} \tau+\left(1-(1-\kappa)^{\frac{\delta}{\eta}}\right) \mathrm{NP}$

N حجم Fاز طبيعى برحسب متر مكعب در هر سال، P: قيمت كاز طبيعى برحسب دلار بهازاى

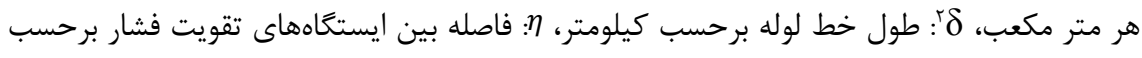

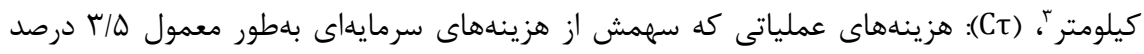

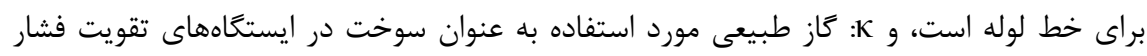
I. يكى از يركاربردترين فولادها در خطوط يرفشار انتقال كاز طبيعى، فولاد API X-70 است. يزوهش روى

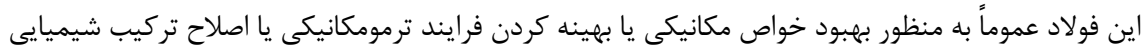
آن متمركز شده است.

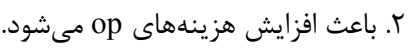

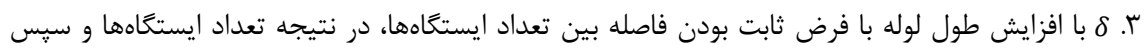
هزينهها افزايش مى بابد. 


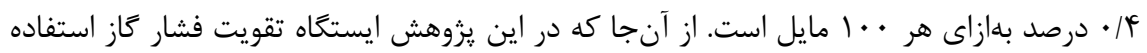
نمىشود، يس هزينه عملياتى فقط شامل ه/ ب درصد از هزينه سرمايهاى براى ساخت ايستخاه تقليل

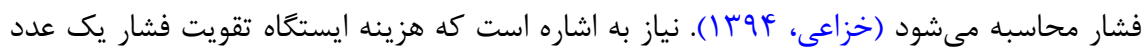
ثابت در نظرگرفته مىشود و شامل كل هزينه ماست.

هزينه سرمايهاى در انرزى خورشيدى و بادى به عنوان عملكردى توان نامى' (

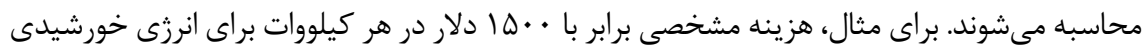

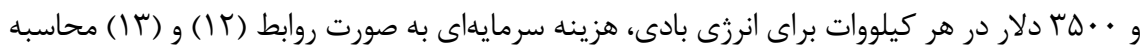

$C_{C E, P V}=1500 \times P_{e l, P V}$ مىشود.

$C_{C E, W T}=3500 \times P_{e l, W T}$

جمع هزينه سرمايهاى و هزينه نصب و راهاندازى را هزينه اوليه مَى گويند كه به صورت رابطه

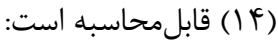

$C_{I C}=C_{C E}+C_{\text {install }}$

علاوه بر اين، سيستم انرزى تجديديذير داراى هزينه سرمايهاى سيستم ذخيرهسازى ( ( است كه به صورت تابعى از هزينه براى هر كيلووات ساعت از ظرفيت انرزى سيستم ذخيرهسازى و هزينه سرمايهاى مبدل برق (CE,inverter

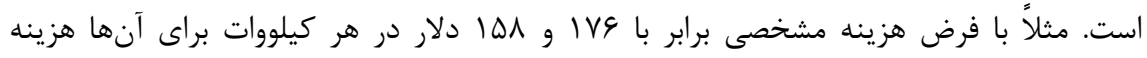

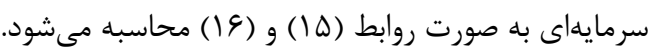

$C_{C E, L A B}=176 \times$ Capacity $_{L A B}$

$C_{C E, \text { Inverter }}=158 \times P_{e l, P V}$

بنابر اين، باجمع هزينهایى فوق، كل هزينه سرمايهاى اوليه بهدست خواهد آمد (Buonomano etal.,2018): $C_{\text {tot }, C E}=C_{I C}+C_{C E, L A B}+C_{C E, \text { Inverter }}$

براى انجام مقايسه ابتدا با توجه به زَارشهاى مصرف در شهرستان گاز شهرستان انديكا و با 
توجه به تعداد روستاهاى اين شهرستان، متوسط مصرف گاز ساليانه براى هر روستا محاسبه مىشود

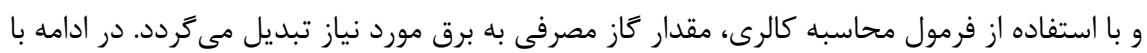

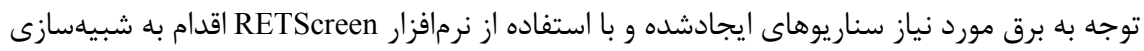

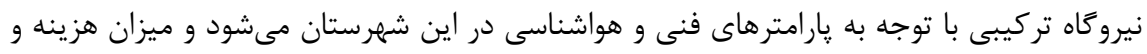
در آمد محاسبه و مقايسه مى در اين يزوهش، مقايسهاى بين نيروكاه تركيبى و خط انتقال گاز در شهرستان انديكا استان خوزستان انجام مىشود. اين شهرستان ازجمله شهرستانهاى در حال گسترش استان خوزستان است

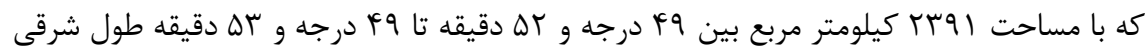

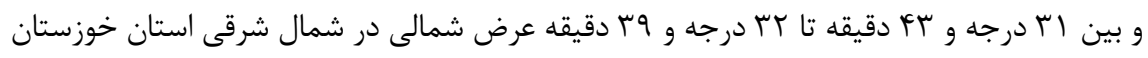
و تقريباً در مركز رشتهكوههاى زاگرس واقع شده است. انديكا در شمال شرقى استان خوزستان قرار دارد و از شمال غرب به لالى، از شمال به سردشت دزفول، از شمال و شمال شرق به استان جهارمحال

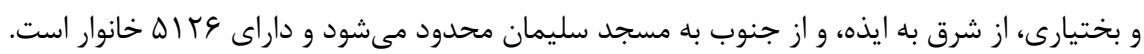

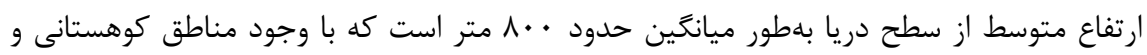
صعبالعبور، كاز طبيعى لوله كشى در برخى از روستاهاى اين شهرستان انجام نشده و سوختهاى

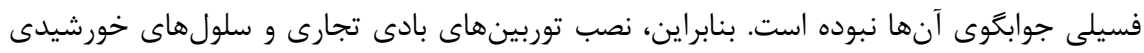

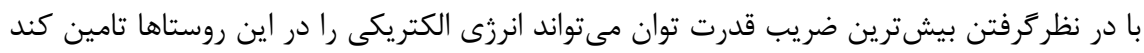

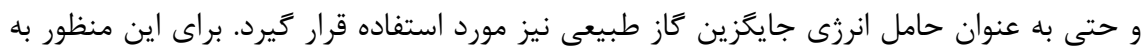
بررسى و مقايسه نيروگاه تركيبى خورشيدى ـ بادى با خط انتقال انجام مى گيرد.

تجزيهوتحليل اطلاعات

\section{محاسبه برق مورد نياز}

در جدول (ז)، آمار تعداد روستاها، تعداد خانوار، ميزان گاز مصرفى، و برق مصرفى خانوار روستايى

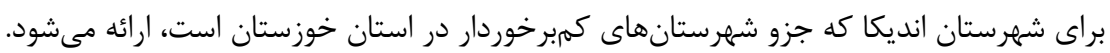




\begin{tabular}{|c|c|}
\hline شهرستان انديكا & شهرستان \\
\hline 14 & تعداد روستا \\
\hline $1.91 \pi$ & 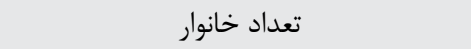 \\
\hline 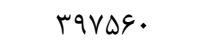 & متراز لوله كذارى مورد نياز \\
\hline kiq. & تعداد انشعاب گَاز مورد نياز \\
\hline 9 & تعداد ايستخاه تقليل فشار كاز مورد نياز \\
\hline $1 \cdot r \backslash \Lambda V / \Gamma$ & متوسط كاز مصرفى هر روستا (متر مكعب) \\
\hline
\end{tabular}

براى انجام يك مقايسه بهتر بين استفاده از انرزى تجديديذير و ₹از طبيعى، ابتدا بايد اين مقايسه

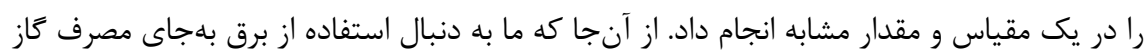
طبيعى هستيم، ابتدا بايد ميزان متوسط كاز مصرفى هر روستا را تبديل به به برق مصرفى هر مر روستا مانه

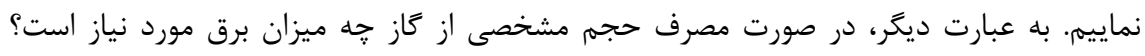

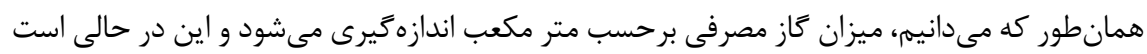

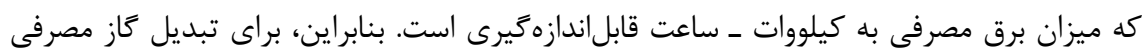

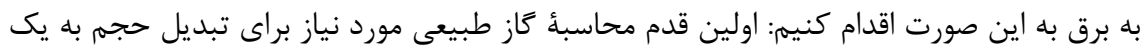

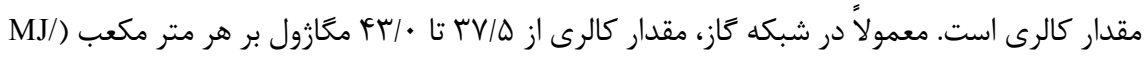

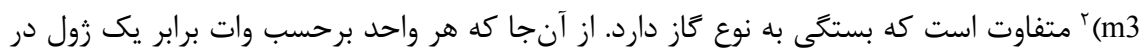
ثانيه است، بنابراين خواهيم داشت (Byrom, 2019):

\section{$1 W=1 \quad J / S \Rightarrow 1 \quad k W h=1 * 1000 * 60 * 60 J \Rightarrow 1 \quad k W h=3.6 \quad M J$}

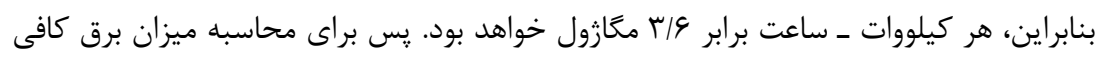

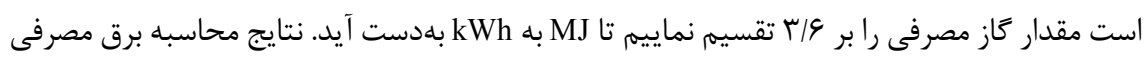
بهجاى گاز در جدول (rا) براى شهرستان انديكا محاسبه شده است. 
جدول "ז: ميز ان برق مصرفى مورد نياز شهرستان انديكا'

\begin{tabular}{|c|c|}
\hline 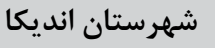 & محاسبات \\
\hline $1 \cdot r I \Lambda V / r$ & متوسط گاز مصرفى هر روستا (متر مكعب) \\
\hline TIIDF/TH & متوسط برق بهجاى گاز براى روستا (مغاوات ساعت سالانه) \\
\hline mIGT & متوسط برق مصرفى بهجاى كاز روستا (كيلووات روزانه) \\
\hline
\end{tabular}

\section{ظرفيت بالقوهُ نيروى باد}

به منظور سنجش ظرفيت بالقوه انرزى بادى، ابتدا آمار دهساله مربوط به سرعت باد براى شهرستان

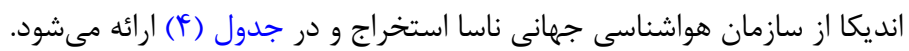

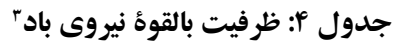

\begin{tabular}{|c|c|}
\hline شهرستان انديكا & شهرستان \\
\hline$\Delta / 19$ & ميانكين سرعت باد ساليانه \\
\hline f. & ارتفاع سنجش باد (متر) \\
\hline • ال ساله & ميانگين دوره \\
\hline
\end{tabular}

منبع: سازمان هو اشناسى ناسا"

در شكل (1) نيز توزيع تجمعى سرعت باد ارائه شده است. در اين محاسبات ضريب اعوجاج Weiboll

ا. محاسبات در دو بخش صورت گرفته است. ابتدا محاسبات بر اساس منطقه مورد بررسى انجام كرفته كه شامل جندين روستا بوده و سيس اين محاسبات بر اساس ميانگين براى يك روستا در نظر گرفته شده است.

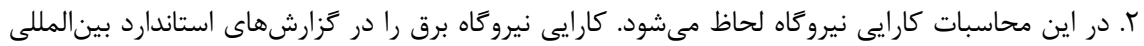
حدود rr درصد لحاظ مى كنند. r. در محاسبات از نرمافزار RETScreen و اطلاعات آبوهواى ناسا كه متصل به نرمافزار است، استفاده شده 


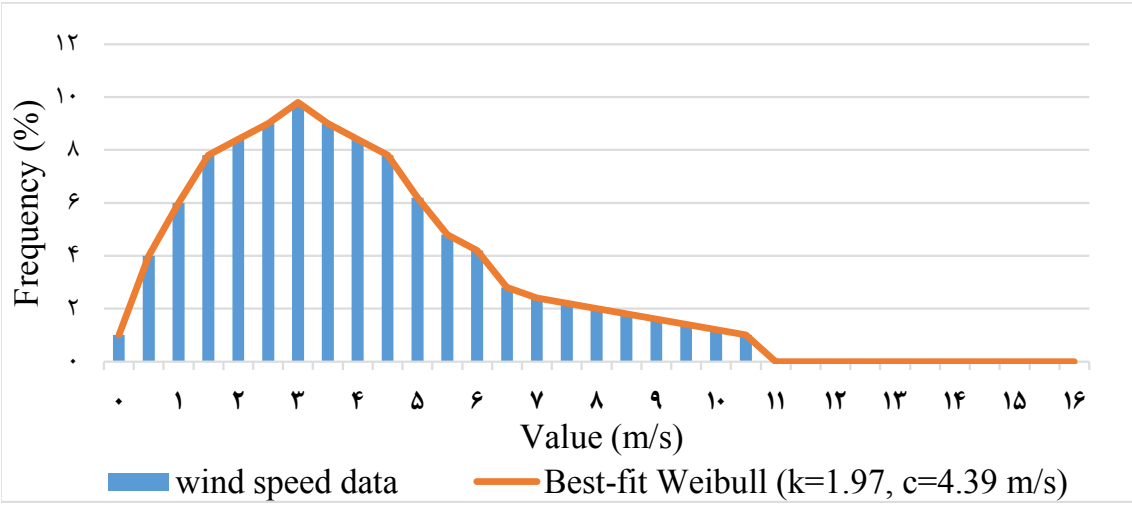

شكل ا: توزيع تجمعى سرعت باد

\section{ظرفيت بالقوه انرزى خورشيدى}

ميانگين ساليانه ظرفيت بالقوه انرزى خورشيدى شهرستان انديكا در جدول (ه) ارائه شده است.

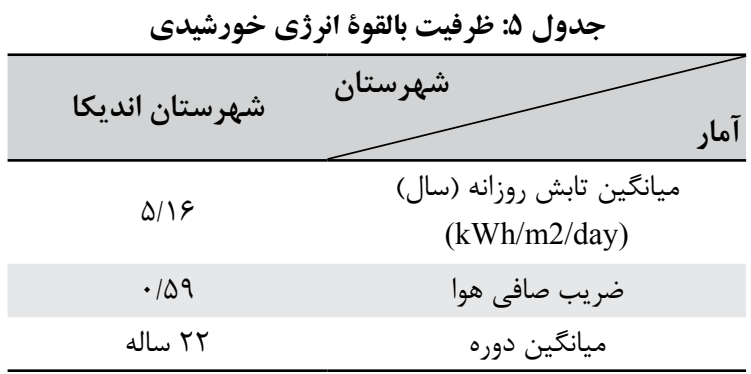

منبع: سازمان هواشناسى ناسا

همجٍنين، دادهاى ميانگين ماهانه تشعشع خورشيد براى منطقه در شكل (r) نمايش داده شده است. خط قرمزى كه در نمودار ديده مىشود، شاخصى است كه تحت عنوان شفافيت معرفى ميىشود. شاخص شفافيت نسبت تابش خورشيدى سطح زمين به تابش خورشيدى جوّ است كه تغييرات آن 


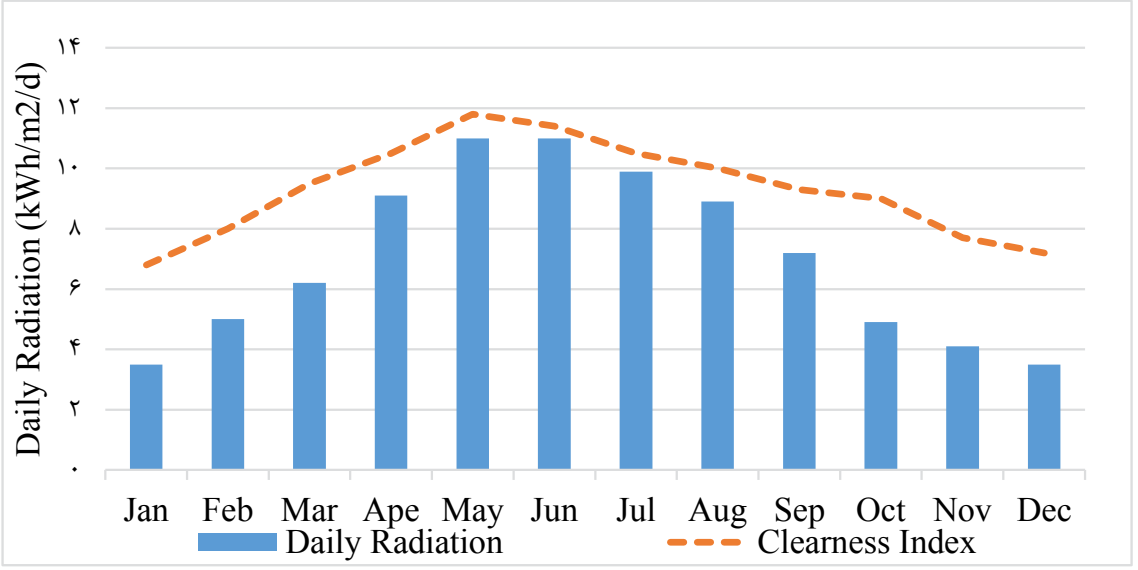

شكل r: تشعشع ماهانه خورشيد

تعيين بار مورد نياز

ييش از انجام شبيهسازى نيروگاه، ابتدا بايد ميزان بار الكتريكى مورد نياز را تعيين نمود. منظور

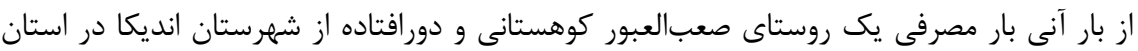
خوزستان است كه به عنوان بار مستقل از شبكه در نظرگرفته شده است. بهطور متوسط، مصرف انرزى بـى

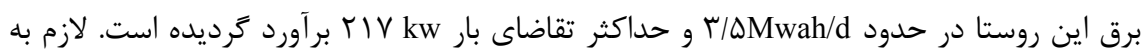

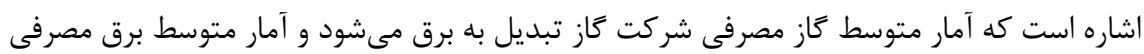
خانوار از آمار شركت توانير' است (جدول ؟ ع).

\begin{tabular}{|c|c|}
\hline شهرستان انديكا & شهرستان \\
\hline $11 \Delta F / T H$ & متوسط مصرف سالانه برق بهجاى گاز (معاوات ساعت) \\
\hline$\Gamma / 19$ & متوسط مصرف روزانه برق بهجاى گاز (مخاوات ساعت) \\
\hline
\end{tabular}


براى يك روز خاص يروفايل مصرف بار روزانه روستا در شكل (ب) مشاهده مىشود.

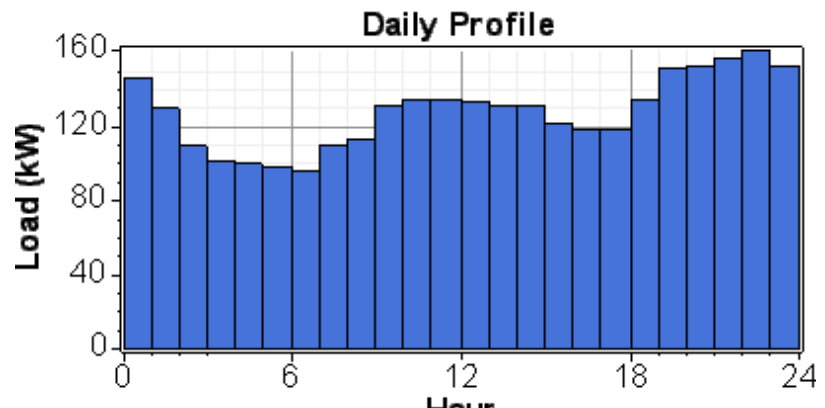

Hour

شكل rا: يروفايل روزانه بار مصرفى'

همان طور كه در شكل (r) نشان داده مىشود، حداكثر بار • •1 كيلووات و حداقل بار 99 كيلووات

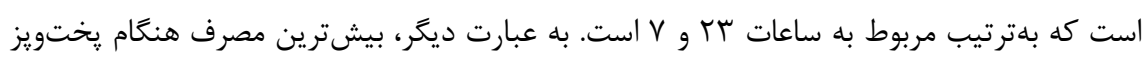

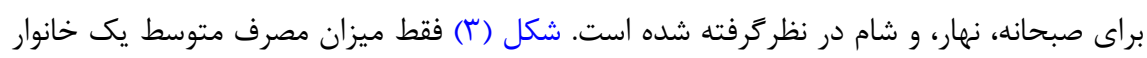

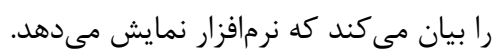

يك سيستم تركيبى اساساً از منابع انرزى تجديديذيرى (شامل انرزى خورشيدى و بادى) كه به له

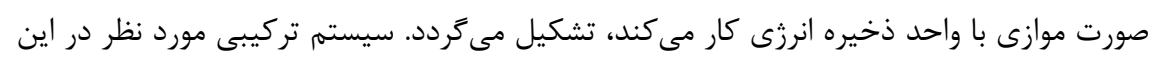

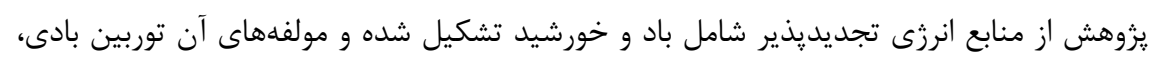

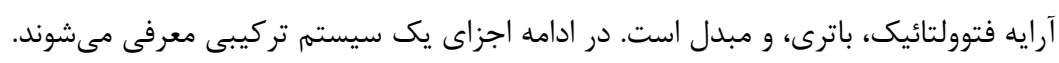

ا. محاسبات با نرمافزار هومر (Homer) انجام شده است. نرمافزار هومر به عنوان شبيهساز سيستمهاى سيكل

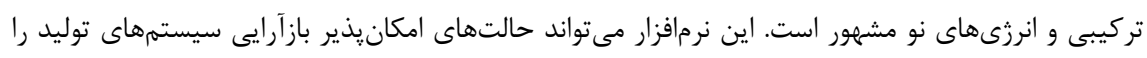

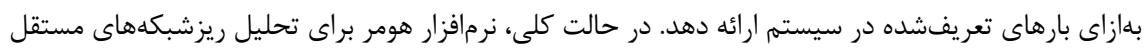

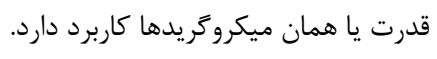




\section{توربين بادى}

در اين يزوهش از توربين بادى برند زيمنس' و مدل AN BONUS 300 kW استفاده شده است.

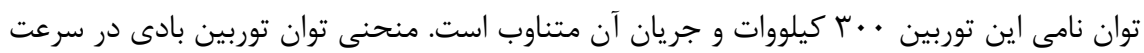
بادهاى متفاوت در شكل (أ) ارائه شده است. توربينهاى بادى در سرعتهاى بالاتر از حد مجاز يك

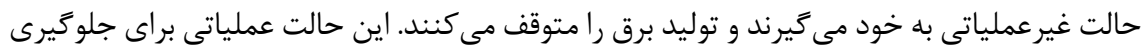
از آسيب به سازه توربين بادى در سرعتهاى باد بالاتر از حد مجاز است. دليل انتخاب توربين مذكور

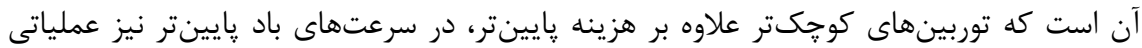

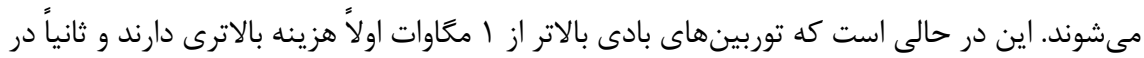
سرعتهاى باد پايين معمولاً خروجى ندارند (Nersesian, 2016).

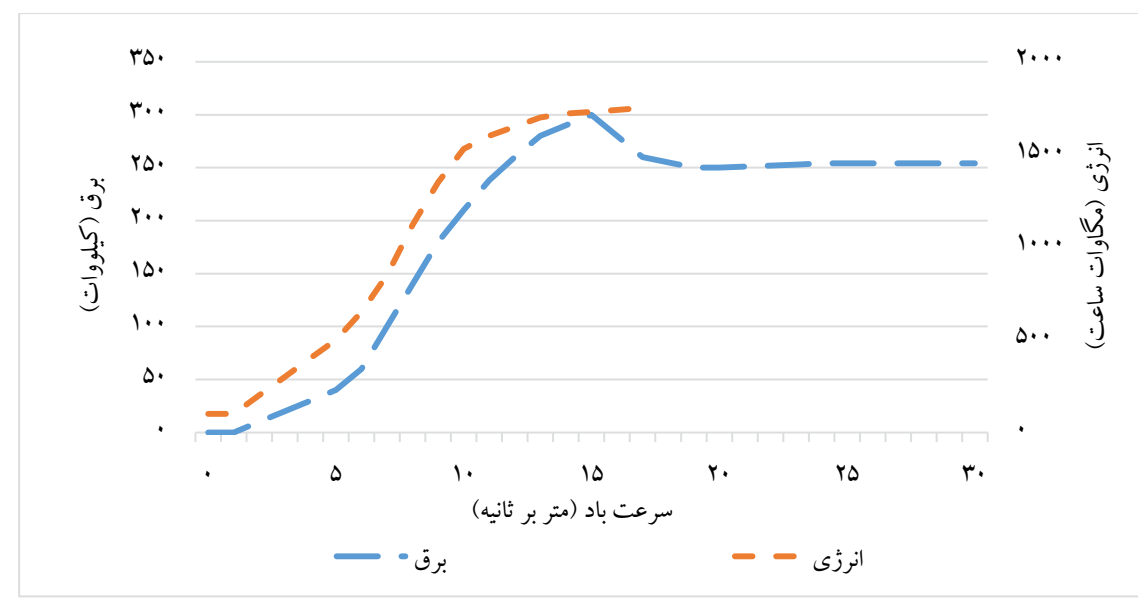

شكل ^^: توان خروجى توربين بادى'

\section{Siemens}




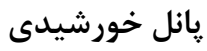

پانل خورشيدى سانياور' مدل E20 از بين يانلهاى خورشيدى با بهرهورى و ظرفيت بالا انتخاب

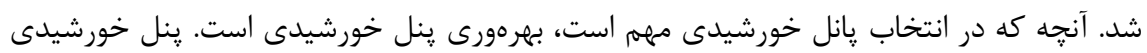
انتخابشده در ميان برندها و همجنين مدلهاى مورد بررسى بيشترين كارايى را دارد كه اطلاعات

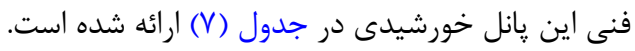

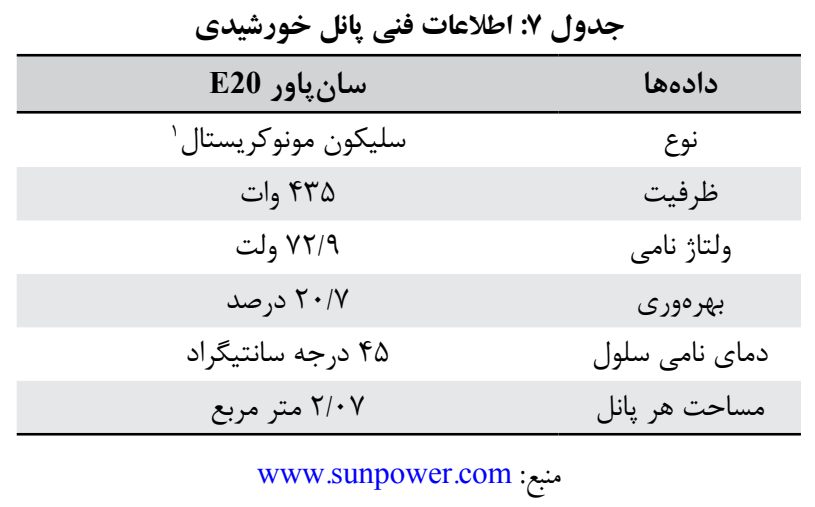

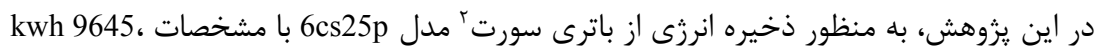

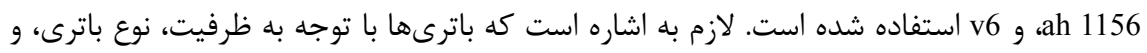
جنس باترى انتخاب مىشوند. انتخاب نوع، جنس، و ظرفيت باترى با مهندسان برق است. در نتيجه،

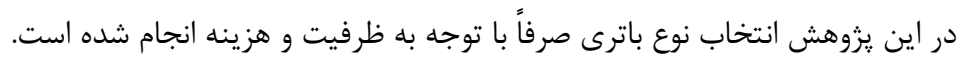




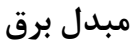

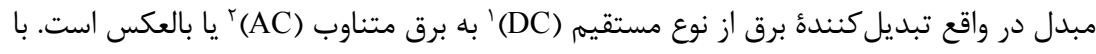

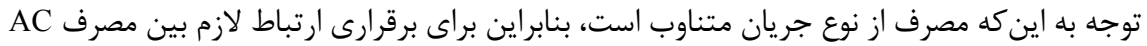
و توليد DC به مبدل الكترونيك قدرت لازم است. براى اين منظور از يك مبدل kw . . " استفاده شده است. ظرفيت مبدل با توجه به ظرفيت يانل خورشيدى تعيين شده است، جرا كه خروجى توربين

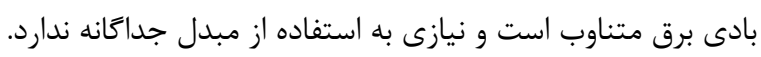

\section{ظرفيت سيستم تركيبى}

براى انجام شبيهسازى يك سيستم تركيبى ابتدا بايد جند سناريو از اندازه اجزاو سيستم تركيبى

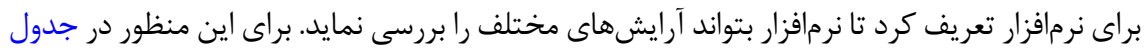
(1) سناريوهاى مختلف را براى پانل خورشيدى، توربين بادى، باترى، و مبدل توان ارائه شده است.

جدول ^: فضاى تركيبهاى مختلف براى سيستم تركيبى

\begin{tabular}{|c|c|c|c|c|c|}
\hline توان سيستم تركيبى & (كيلووات) & (تعاترى & 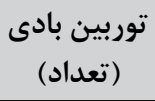 & "ِانل خورشيدى (كيلووات) & سناريو \\
\hline 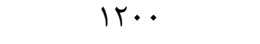 & . . & $I V \vee \Delta$ & . & M. & 1 \\
\hline 15. & שrז. & $11 \mathrm{VD}$ & 1 & $9 \ldots$ & $r$ \\
\hline 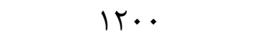 & $1 \Delta \Delta$ & $11 V \Delta$ & $r$ & G.. & $r$ \\
\hline Ir.. & $\Lambda$. & $11 \mathrm{VD}$ & r & r.. & f \\
\hline $15 \ldots$ & - & - & f & - & $\Delta$ \\
\hline
\end{tabular}

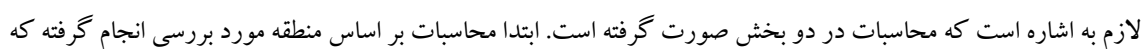

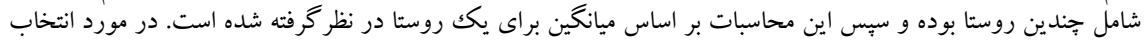

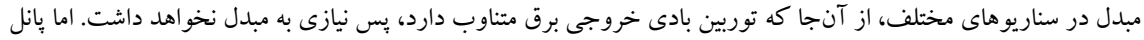

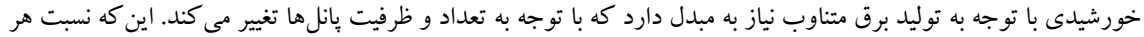

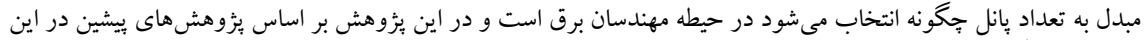

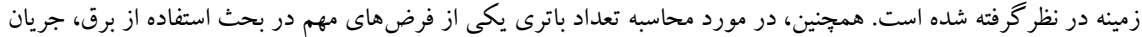

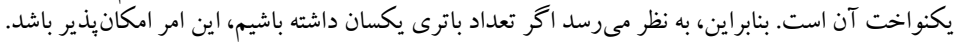

1. Direct Current

2. Alternating Current 


\section{شبيهسازى نيروكاه}

به منظور شبيهسازى از نرمافزار RETScreen استفاده شده و با توجه به يارامترهاى كليدى

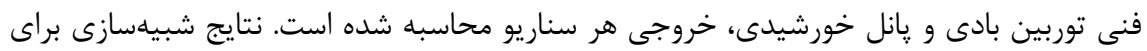
شهرستان انديكا در جدول (9) ارائه شده است. در اين جدول، ميزان توليد انرزى الكتريكى كل سيستم و همجنين سهم هر كدام از انرزى خورشيدى و بادى از كل توليد سيستم ارائه شده است.

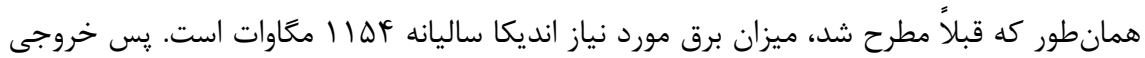
نرمافزار نيز بر اساس توليد برق ساليانه در نظرگرفته شده است.

جدول 9: ميزان توليد انرزى الكتريكى ساليانه شهرستان انديكا

\begin{tabular}{|c|c|c|c|c|c|}
\hline \multirow{2}{*}{ سيستم (مكاوات) } & \multicolumn{2}{|c|}{ توربين بادى (مكاوات) } & \multicolumn{2}{|c|}{ نيروگاه خورشيدى (مكاوات) } & \multirow{2}{*}{ سناريو } \\
\hline & سهمم توليد (درصد) & ميزان توليد & سهم توليد (درصد) & ميزان توليد & \\
\hline $1910 / 90$ & - & - & $1 \cdots$ & $1910 / 90$ & 1 \\
\hline $19 \cdot r / 1 r$ & $r \Delta$ & IS\&IOV & $V \Delta$ & $|F T g| \Delta G$ & r \\
\hline $1191 / 4 r$ & pq & ( & $\Delta 1$ & $9 \Delta \Lambda / I V$ & r \\
\hline$|\wedge V \wedge / \Lambda|$ & $V \Delta$ & Irq9/V & ra & 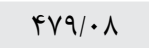 & f \\
\hline$|\Lambda \& \& / \Gamma|$ & $1 \ldots$ & $|\Lambda \& \& / \Gamma|$ & - & - & $\Delta$ \\
\hline
\end{tabular}

براى شهرستان انديكا به منظور مقايسه بهتر بين سناريوها، سهمم هر كدام از انرزىها در كل توليد سيستم تركيبى براى هر ماه در شكلهاى (ل) و (9) ارائه شده است. 


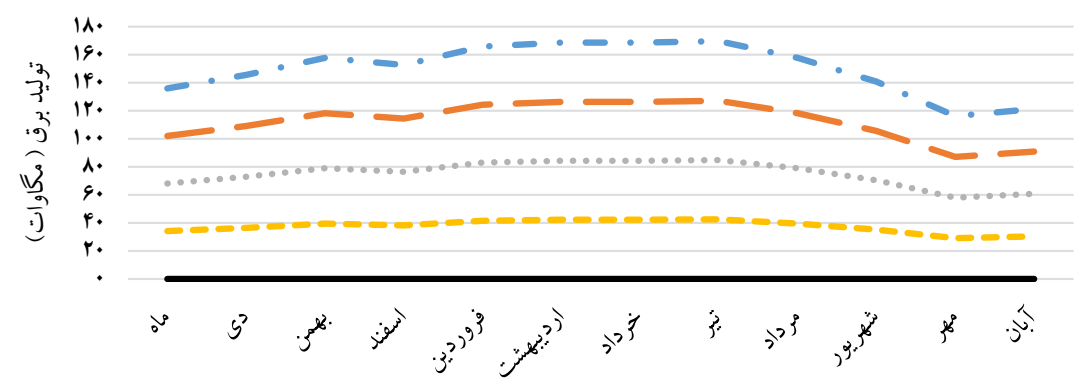

ماه سال

سناريو ه س سناريو

شكل ه: ميزان توليد سناريوهاى مختلف در نيروكاه خورشيدى شهرستان انديكا

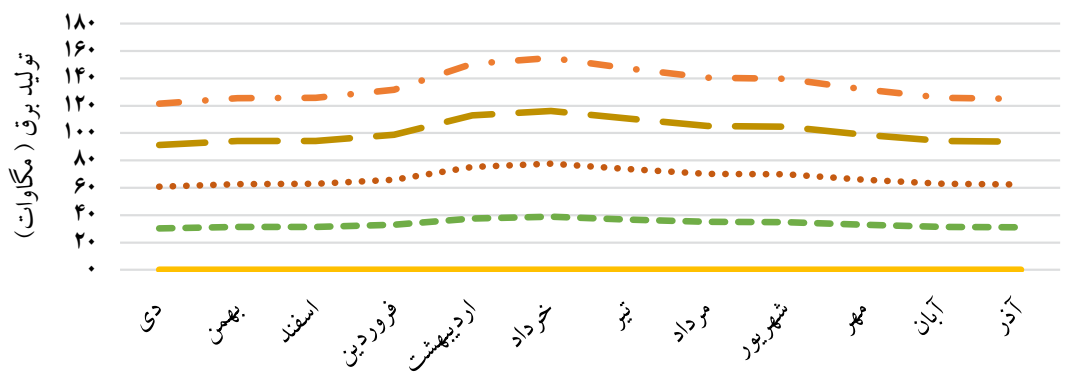
ماه سال

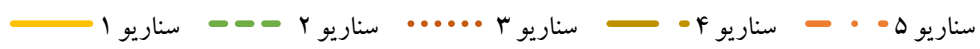

شكل \&: ميزان توليد سناريوهاى مختلف در توربين بادى شهرستان انديكا 
محاسبه هزينه

\section{هزينه خط انتقال كاز}

با توجه به فرمولهاى (9)، (• (1)، و (11) مىتوان هزينه سرمايهاى و عملياتى را محاسبه نمود. در جدول (• () هزينه انتقال كاز بهطور متوسط براى يك روستا در شهرستان انديكا ارائه شده است.

جدول • ا: هزينه انتقال كاز (ميليون دلار)'

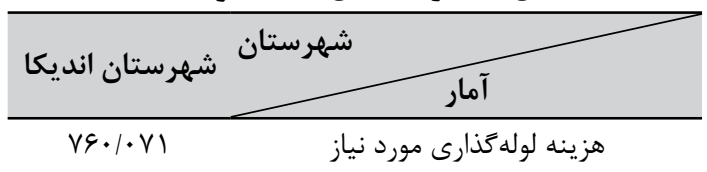

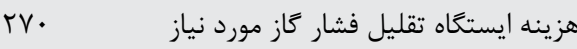

جمع هزينه سرمايهاى انتقال كاز

هزينه عملياتى انتقال كاز

متوسط هزينه سرمايهاى براى هر روستا

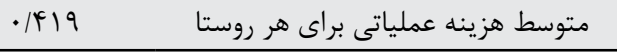

منبع: شركت ملّى كَاز ايران

متوسط هزينهاى سرمايهاى و عملياتى براى هر روستا از تقسيم جمع هزينهاى سرمايهاى و

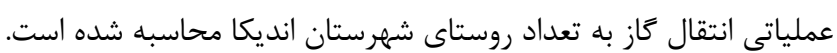

\section{هزينه نيروكاه تر كيبى}

به منظور محاسبه هزينه سيستم تركيبى تجديديذير ابتدا لازم است برخى يارامترهاى كليدى

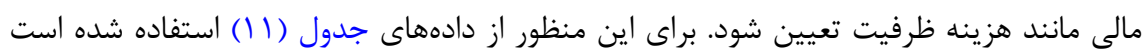
(صادقى و بهروزه، و (1) (1).

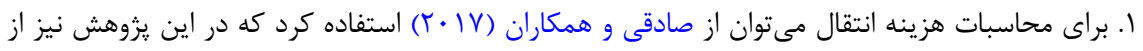
اين روش استفاده شده است. 
جدول 1/: هزينه سيستم تر كيبى تجديديذير (دلار در هر كيلووات ساعت)

\begin{tabular}{|c|c|c|c|c|c|c|c|c|}
\hline \multicolumn{2}{|c|}{ باترى } & \multicolumn{2}{|c|}{ مبدل برق } & \multicolumn{2}{|c|}{ توربين بادى } & \multicolumn{3}{|c|}{ نيروكاه خورشيدى } \\
\hline عملياتى & ظرفيت & عملياتى & ظرفيت & عملياتى & ظرفيت & عملياتى & ظرفيت & . . . \\
\hline 4 & $\Delta \cdot$. & $r$. & r.. & $\Delta$. & $r \cdot r$. & TF & THG. & ري \\
\hline
\end{tabular}

همانطور كه در جدول (1) مشاهده مىشود، در نيروكاه خورشيدى هزينه ظرفيت بيشتر از

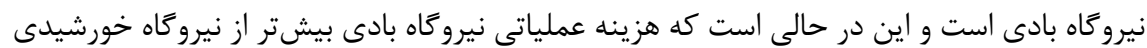
است. پس با توجه به اطلاعات ارائهشده در جدول (1) و همجنين ظرفيتهاى هر سناريو جدول (^) هزينه هر سناريو در جدول (Y () برحسب ميليون دلار ارائه شده است.

جدول r ا: هزينه سيستم تر كيبى تجديديذير (ميليون دلار)

\begin{tabular}{|c|c|c|c|c|c|}
\hline سناريو ه & سناريو F & سناريو r & سناريو r & سناريو 1 & شهرستان \\
\hline T/FTY & $1 / 1 / 1$ & $1 / 4 I T$ & $.19 \cdot 9$ & - & هزينه سرمايهاى نيروگاه بادى \\
\hline- & $\cdot / \cdot \mathrm{v} \cdot$ & $1 / 419$ & T/ITF & T/ATt & هزينه سرمايهاى نيروكاه خورشيدى \\
\hline- & $\cdot / \cdot r t$ & .1 .94 & .1 .94 &.$/ 14$ & هزينه سرمايهاى مبدل \\
\hline- & . ITHD & $\cdot / F \Delta V$ & $.1 \cdot 9 \wedge$ & $\cdot \mid \wedge \Lambda$ & هزينه سرمايهاى باترى \\
\hline T/FTY & r/Vqr & r/IFV & $r / D \cdot r$ & r/Arq & جمع كل هزينه سرمايهاى \\
\hline $.1 \cdot 9$ & $\cdot 1 \cdot 4 \Delta$ & $\cdot / \cdot r$ & $.1 \cdot 10$ & - & هزينه عملياتى نيرو \\
\hline- & $\cdot 1 \cdot \cdot V$ & $\cdot 1 \cdot 1 \mathrm{f}$ & $\cdot \mid \cdot 4 I$ & $\cdot / \cdot r \Lambda$ & هزينه عملياتى نيروگاه خورشيدى \\
\hline- & $\cdot 1 \cdots 1$ & $\cdot / \cdot r$ & 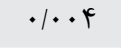 & $\cdot 1 \cdot .9$ & هزينه علمياتى مبدل \\
\hline- & $\cdot / \cdot r$ & $\cdot 1 \cdot \theta$ & $\cdot / \cdot \wedge$ & $.1 \cdot 1 \cdot$ & هزينه علمياتى باترى \\
\hline $.1 \cdot 9$ & $\cdot / \cdot \Delta \varphi$ & $\cdot / \cdot \Delta r$ & .1 .49 & $\cdot 1 \cdot 14 \Delta$ & جمع كل هزينه عملياتى \\
\hline
\end{tabular}

هزينه سر مايهاى = هزينه ظرفيت براى هر كيلووات × ظرفيت توليد بانل خورشيدى به كيلووات 


\section{محاسبه در آمد}

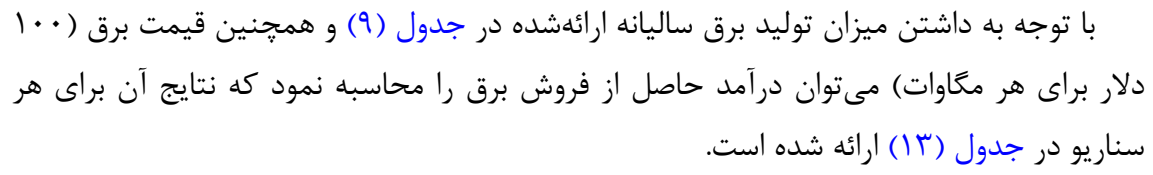

جدول rا ا: محاسبه در آمد حاصل از فروش برق (دلار)

\begin{tabular}{|c|c|c|c|c|c|}
\hline سناريو ه & سناريو F & سناريو r & سناريو r & سناريو 1 & سناريو \\
\hline 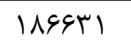 & $|\wedge \vee \wedge \Lambda|$ & $1 \wedge 914 \%$ & $19 \cdot r \mid r$ & 191090 & در آمد \\
\hline
\end{tabular}

در آمد فروش گاز

همجٍنين، با توجه به ميزان متوسط مصرف گاز براى يك روستا كه در جدول (Y) ارائه شده است،

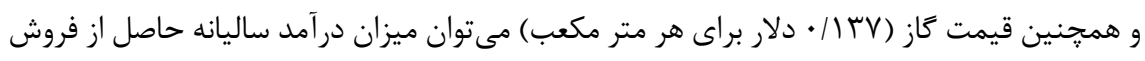

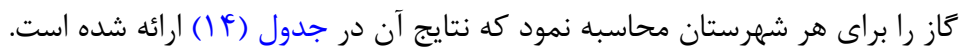

جدول f أ: محاسبه در آمد حاصل از فروش كاز (دلار)

در آمد




\section{مقايسه خط انتقال كاز و نيرو Fاه تركيبى}

\section{مقايسه هزينه}

در شكل (V)، هزينه سرمايهاى انتقال گاز با سناريوهاى مختلف نيروگاه تركيبى ارائه شده است.

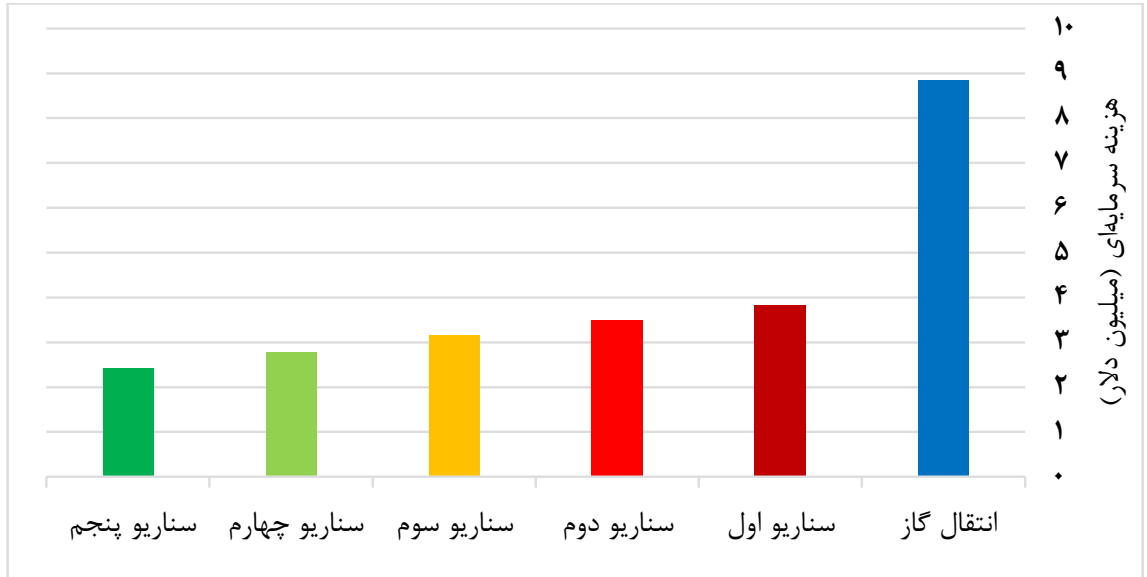

شكل \: مقايسه هزينه سرمايهاى انتقال Fاز و نيروكاه تركيبى شهرستان انديكا

همانطور كه مشاهده مىشود، يك اختلاف بيش از دوبرابرى بين هزينه سرمايهاى انتقال كاز و

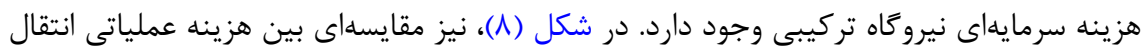
كاز و هزينه عملياتى نيروگاه تركيبى ارائه شده است. 


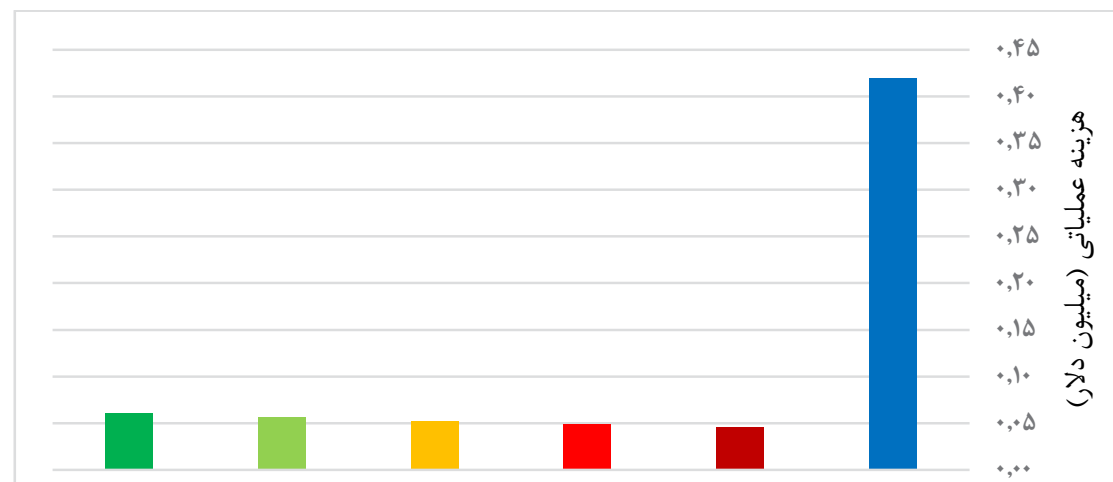

انتقال گاز سناريو اول سناريو دوم سناريو سوم سناريو جهارم سناريو ينجم

شكل 1: مقايسه هزينه عملياتى انتقال Fاز و نيروكاه تركيبى

همانطور كه مشاهده مىشود، هزينه عملياتى يك نيرو انتقال كاز است.

مقايسه در آمد

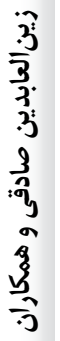

در شكل (9)، مقايسهاى بين درآمد حاصل از فروش برق و همجنين درآمد حاصل از فروش كاز

ارائه شده است.

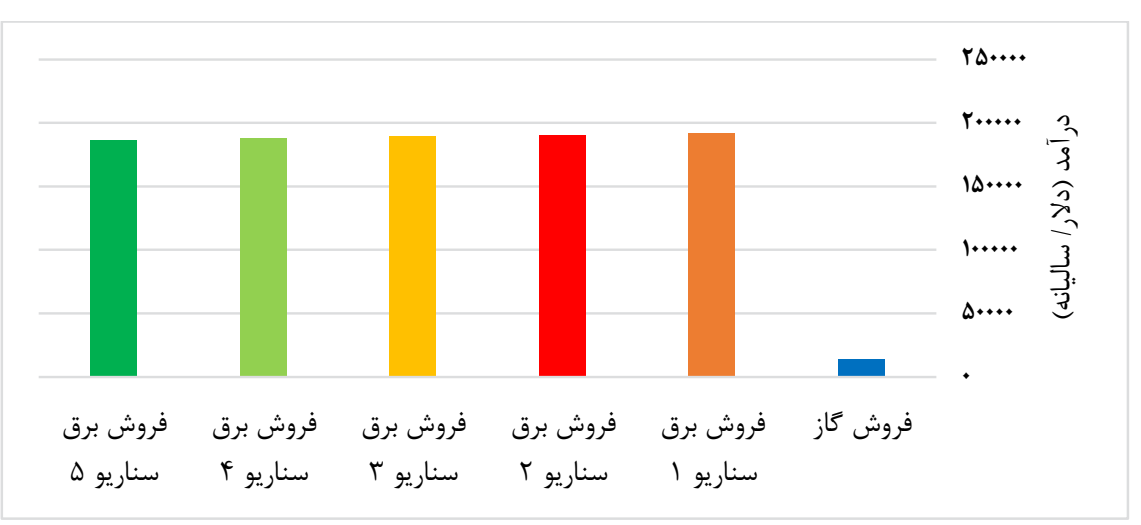


همانطور كه شكل (9) نشان مىدهد، با توجه به مقدار متوسط گاز مصرفى در نظرگرفتهشده،

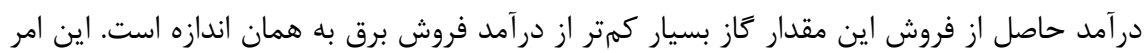

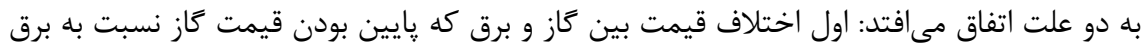
است، و دوم مقدار بالاتر مصرف برق بهجاى همان مقدار كاز است.

\section{مقايسه در آمد و هزينه}

در ادامه، مقايسهاى بين درآمد ساليانه حاصل از فروش كاز و برق با هزينه عملياتى ساليانه ارائه

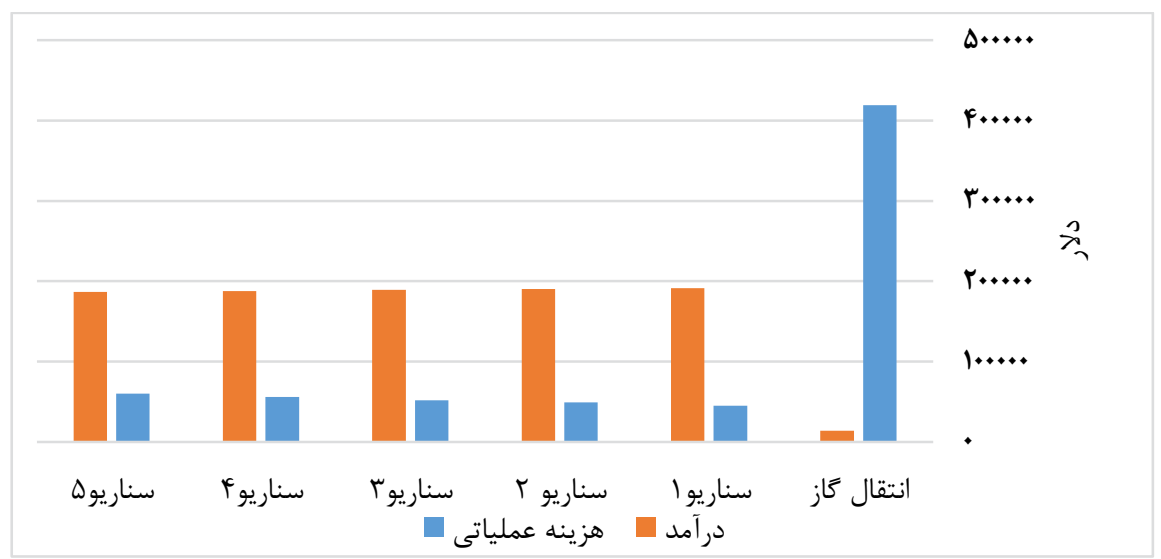

شكل • ا: مقايسه در آمد فروش و هزينه عملياتى در شهرستان انديكا

مقايسه درآمد حاصل از فروش برق و كاز با هزينه عملياتى (شكل • () نشان مىدهد، در اين

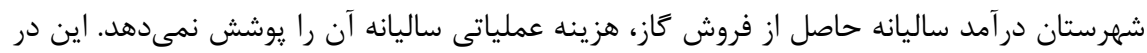
حالى است كه بهطور متوسط درآمد ساليانه حاصل از فروش برق بيش از سهبرابر هزينه عملياتى ساليانه هر نيروگاه است.

\section{بحث و نتيجه كيرى}

هدف اصلى اين يروهش، مقايسه اقتصادى و فنى تامين انرزى از نيروكاه تركيبى خورشيدى-بادى 
بهجاى احداث خط انتقال كاز طبيعى در شهرستان انديكا است. در اين يزوهش، يك مقايسه هزينه

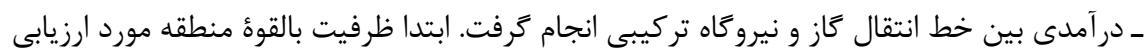

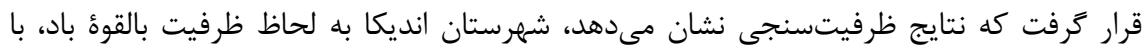
توجه به ميانگين سرعت باد ساليانه، بستر مناسبى دارد. بررسى ساعات سرعت باد نيز نشان مى دهد، افزايش و كاهش سرعت باد به لحاظ ساعت روزانه اينگ

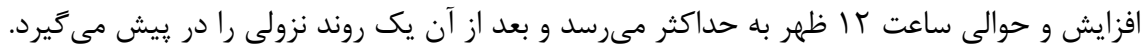
اين در حالى است كه بيشترين مصرف كاز هم مربوط به ساعت استفاده از اجاق كاز براى تهيه غذا و مترادف با همين ساعات اوج سرعت باد است. نتايج ظرفيتسنجى انرزى خورشيدى نيز نشان از بستر

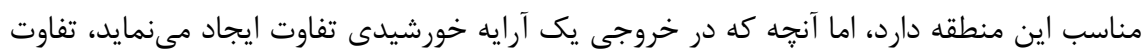
آبوهوايى و كيفيت صافى هواست. همانطور كه در جدول (^) ارائه شد، در سناريوسازى دو مبحث مورد توجه قرار گرفت. ابتدا

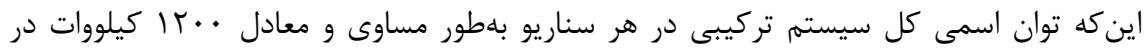

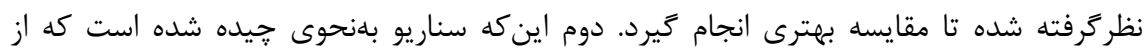

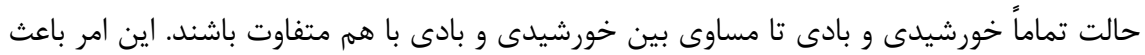

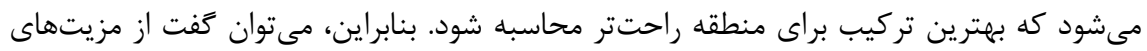

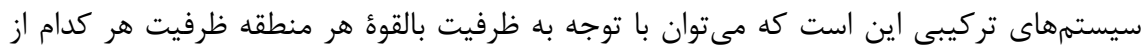

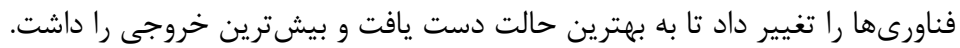

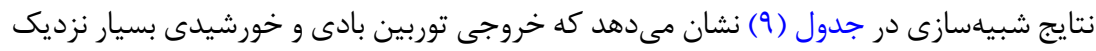

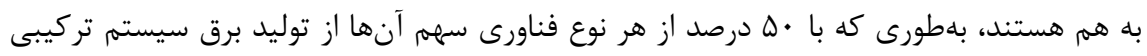

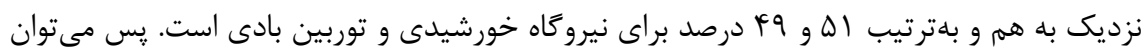

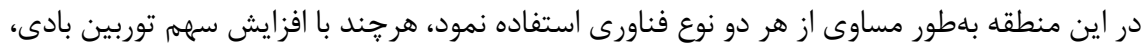
خروجى كل كاهش يیدا كرده است. محاسبه هزينهها نشان مىدهد كه در هزينه انتقال گاز، علاوه بر متراز لولهكذارى، عواملى بـى همجون تعداد روستا، تعداد ايستخاه تقليل فشار، و فاصله بين روستاها نيز تاثير گذار است. هر جه تعداد روستا بيشتر باشد، تعداد ايستخاه تقليل فشار نيز بيشتر مىشود. يُ علاوه بر هزينه سرمايهاى،

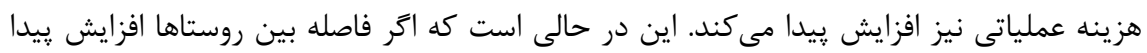




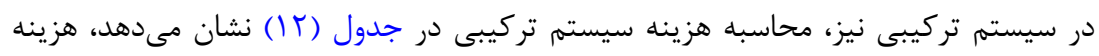

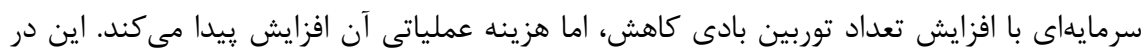

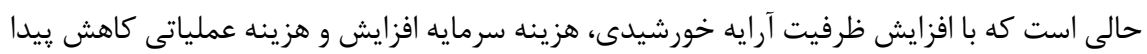

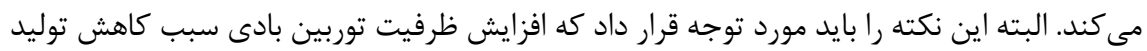

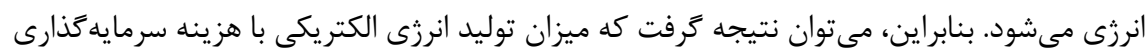
انرزى خورشيدى رابطه مستقيم دارد.

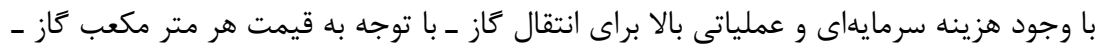

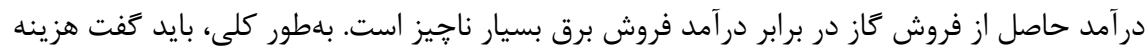

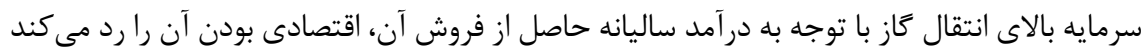

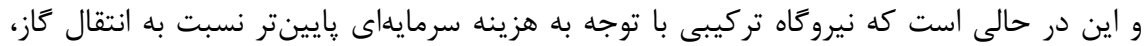

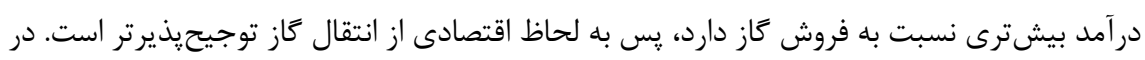

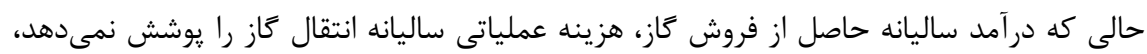

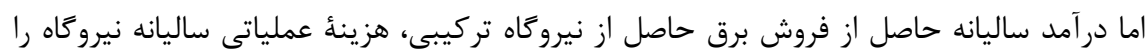
يوشش مىدهد. بلهور كلى، مىتوان كفت كه انتقال كاز هزينأ سرمايهاى و عملياتى بسيار بالاترى

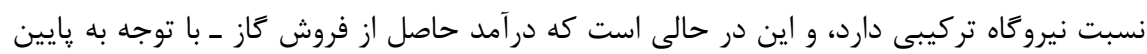

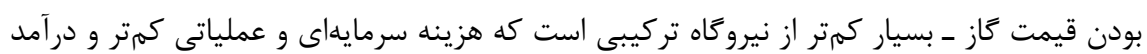
حاصل از فروش برق بيشترى دارد.

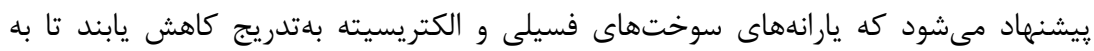

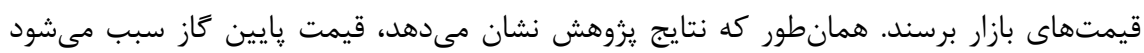

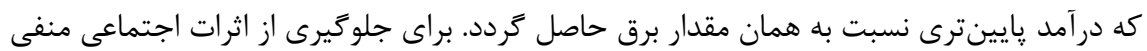

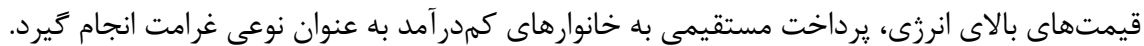

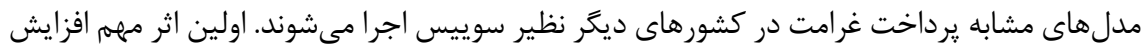

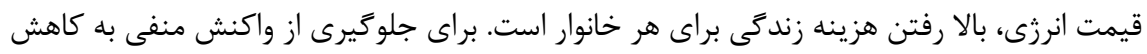

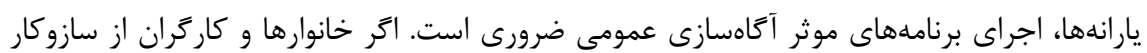

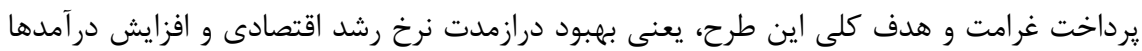

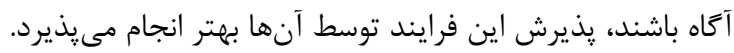
تا زمانى كه سوددهى سرمايهذَذارى در تاسيسات خورشيدى قوام نيام نيافته است، دولت ايران بائ بايد 
حمايت مالى خود را به سرمايهَذارانى كه مىخواهند تاسيسات انرزى تجديديذير مانند خورشيدى و بادى راهاندازى كنند، ادامه دهد. جدا از سرمايهَّارى بخش خصوصى، دولت ايران بايد در در توسعه انرزى خورشيدى از طريق ايجاد يك آزانس تخصصى يا شركتهاى ييمانكار سرمايه گذارى كند.

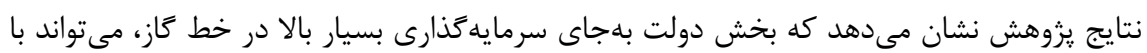

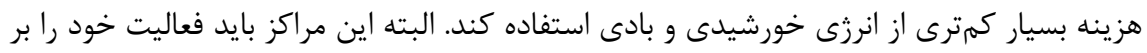

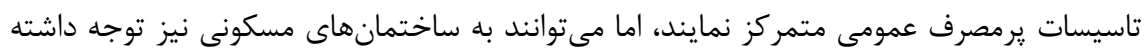

اگر شرايط بازار براى انرزى خورشيدى طبق ييشنهادهاى فوق اجرا گردد، انرزى خورشيدى

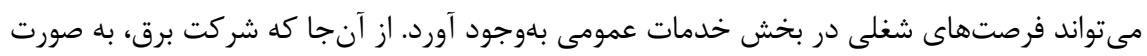

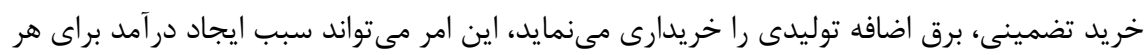

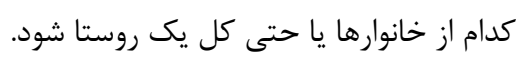

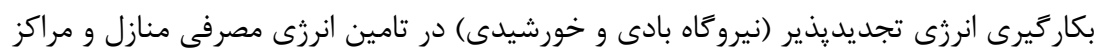

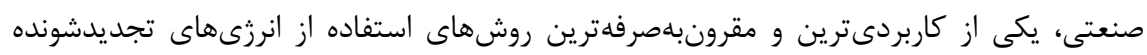
در جهان امروزى است و به همين دليل بيشتر كشورهاى ييشرفته و در حال توسعه به دنه دنبال

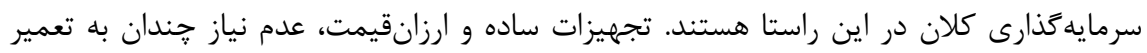

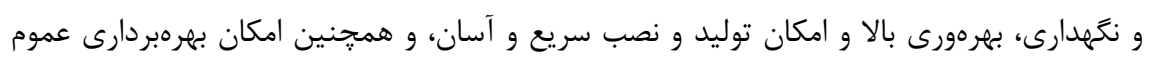

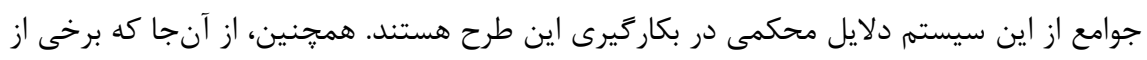

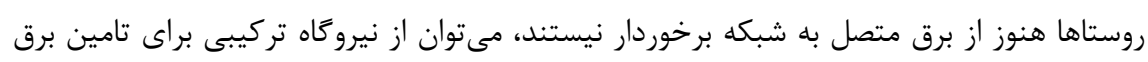

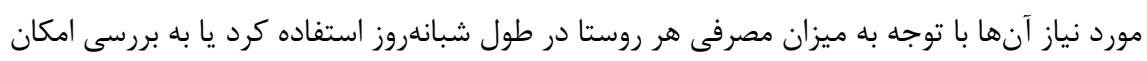

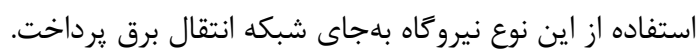

\section{منابع}

Ahmad, J., Imran, M., Khalid, A., Iqbal, W., Ashraf, S. R., Adnan, M.,... Khokhar, K. S. (2018). Techno Economic Analysis of a Wind-Photovoltaic-Biomass Hybrid Renewable Energy System for Rural Electrification: A Case Study of Kallar Kahar. Energy, 148(1), 208-234. https://doi.org/10.1016/j.energy.2018.01.133

BP Statistical Review of World Energy

(2019). Available at: 
https://www.bp.com/en/global/corporate/news-and-insights/press-releases/bp-statistical-review-of-world-energy-2019.html

Buonomano, A., Calise, F., d'Accadia, M. D., \& Vicidomini, M. (2018). A Hybrid Renewable System Based on Wind and Solar Energy Coupled With an Electrical Storage: Dynamic Simulation and Economic Assessment. Energy, 155, 174-189. https://doi.org/10.1016/j.energy.2018.05.006

Byrom, S. (2019). How to Convert Gas Units to KWH. Available at: https://www.theenergyshop.com/guides/how-to-convert-gas-units-to-kwh

Colak, H. E., Memisoglu, T., \& Gercek, Y. (2020). Optimal Site Selection for Solar Photovoltaic (PV) Power Plants Using GIS and AHP: A Case Study of Malatya Province, Turkey. Renewable Energy, 149(1), 565-576. https://doi.org/10.1016/j.renene.2019.12.078

Elmohlawy, A. E., Ochkov, V. F., \& Kazandzhan, B. I. (2019). Thermal Performance Analysis of a Concentrated Solar Power System (CSP) Integrated with Natural Gas Combined Cycle (NGCC) Power Plant. Case Studies in Thermal Engineering, 14(1), 100458. https://doi.org/10.1016/j.csite.2019.100458

Khaleghian, M., Danekar, A., Khorasani, N., Jozi, S. A., Feghhi, J., \& Navabi, G. S. (2012). Environmental Risk Assessment of Gas Pipeline with Method of Muhlbauer (Case Study: Lorestan Province). Journal of Natural Environment, 65(3), 353-365. https://dx.doi.org/10.22059/jne.2012.29789

Maji, I. K. (2015). Does Clean Energy Contribute to Economic Growth? Evidence from Nigeria. Energy Reports, 1(1), 145-150. https://doi.org/10.1016/j.egyr.2015.06.001

Nersesian, R. L. (2016). Energy Economics: Markets, History and Policy: Routledge.

Ramli, M. A., Hiendro, A., \& Al-Turki, Y. A. (2016). Techno-Economic Energy Analysis of Wind/Solar Hybrid System: Case Study for Western Coastal Area of Saudi Arabia. Renewable Energy, 91(1), 374-385. https://doi.org/10.1016/j.renene.2016.01.071

Richardson, D. B. (2013). Electric Vehicles and the Electric Grid: A Review of Modeling Approaches, Impacts, and Renewable Energy Integration. Renewable and Sustainable Energy Reviews, 19(1), 247-254. https://doi.org/10.1016/j.rser.2012.11.042

Sadeghi, Z., Horry, H. R., \& Khazaee, S. (2017). An Economic Evaluation of Iranian Natural Gas Export to Europe through Proposed Pipelines. Energy Strategy Reviews, 18(1), 1-17. https://doi.org/10.1016/j.esr.2017.09.013

Taklif, A. (2013). The Feasibility of Competition or Cooperation amongst GECF Member Countries in Exporting Natural Gas via Pipeline. Iranian Energy Economics, 2(5), 4979. http://jiee.atu.ac.ir/article_773.html

Ulvestad, M., \& Overland, I. (2012). Natural Gas and CO2 Price Variation: Impact on the Relative Cost-Efficiency of LNG and Pipelines. International Journal of Environmental Studies, 69(3), 407-426. https://doi.org/10.1080/00207233.2012.677581

Wang, W.-C., Wang, J.-J., \& Chong, W. T. (2019). The Effects of Unsteady Wind on the Performances of a Newly Developed Cross-Axis Wind Turbine: A Wind Tunnel Study. Renewable Energy, 131(1), 644-659. https://doi.org/10.1016/j.renene.2018.07.061

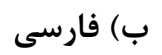


اسماعيلنيا، على اصغر، و زاهدى سرشت، مريم (1 (1) ). بهينهيابى انتقال كاز و برق (همافزايى كاز و برق). نشريه

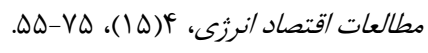

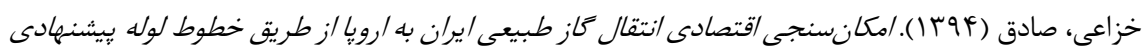

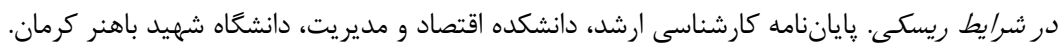

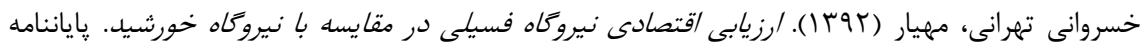

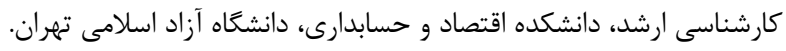

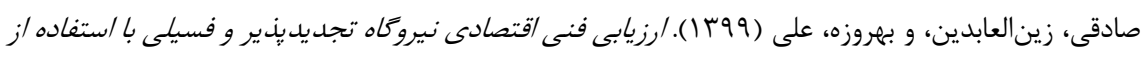

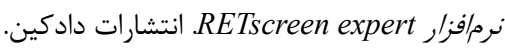

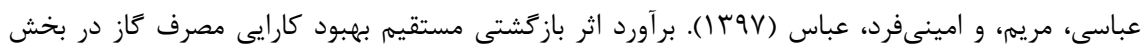

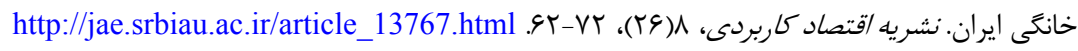

